\title{
Peripheral neuropathy in complex inherited diseases: an approach to diagnosis
}

\author{
Alexander M Rossor, ${ }^{1}$ Aisling S Carr, ${ }_{1}^{1}$ Helen Devine, ${ }^{1}$ Hoskote Chandrashekar, ${ }^{2}$ \\ Ana Lara Pelayo-Negro, ${ }^{1}$ Davide Pareyson, ${ }^{3}$ Michael E Shy, ${ }_{1}^{4}$ Steven S Scherer, ${ }^{5}$ \\ Mary M Reilly ${ }^{1}$
}

- Additional material is

published online only. To view please visit the journal online (http://dx.doi.org/10.1136/ jnnp-2016-313960)

${ }^{1}$ MRC Centre for Neuromuscular Diseases, UCL Institute of Neurology and National Hospital for Neurology and Neurosurgery, London, UK ${ }^{2}$ Lysholm Department of Neuroradiology, National Hospital for Neurology and Neurosurgery, London, UK ${ }^{3}$ Unit of Neurological Rare Diseases of Adulthood, Carlo Besta Neurological Institute IRCCS Foundation, Milan, Italy ${ }^{4}$ Department of Neurology, University of lowa, lowa City, USA

${ }^{5}$ Department of Neurology, University of Pennsylvania, Philadelphia, Pennsylvania, USA

\section{Correspondence to} Professor Mary M Reilly, MRC Centre for Neuromuscular Diseases, 8-11 Queen Square, London, WC1N 3BG, UK; m. reilly@ucl.ac.uk

AMR and ASC contributed equally.

Received 6 January 2017 Revised 7 March 2017 Accepted 8 March 2017 Published Online First 9 August 2017

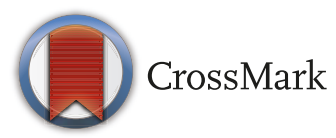

To cite: Rossor AM, Carr AS, Devine $\mathrm{H}$, et al. J Neurol Neurosurg Psychiatry 2017:88:846-863

\section{ABSTRACT}

Peripheral neuropathy is a common finding in patients with complex inherited neurological diseases and may be subclinical or a major component of the phenotype. This review aims to provide a clinical approach to the diagnosis of this complex group of patients by addressing key questions including the predominant neurological syndrome associated with the neuropathy, for example, spasticity, the type of neuropathy and the other neurological and non-neurological features of the syndrome. Priority is given to the diagnosis of treatable conditions. Using this approach, we associated neuropathy with one of three major syndromic categories: (1) ataxia, (2) spasticity and (3) global neurodevelopmental impairment. Syndromes that do not fall easily into one of these three categories can be grouped according to the predominant system involved in addition to the neuropathy, for example, cardiomyopathy and neuropathy. We also include a separate category of complex inherited relapsing neuropathy syndromes, some of which may mimic Guillain-Barré syndrome, as many will have a metabolic aetiology and be potentially treatable.

\section{INTRODUCTION}

Inherited peripheral neuropathies can occur as a 'pure' neuropathy or as part of a more complex neurological or multisystem disorder. Charcot-Marie-Tooth disease (CMT) and the related neuropathies, distal hereditary motor neuropathy (HMN) and hereditary sensory neuropathy (HSN) are the classical 'pure' neuropathies. They commonly present with a characteristic phenotype of a length-dependent, isolated neuropathy progressing over decades. ${ }^{1}$

In the second group of disorders, where neuropathy is part of a more complex disease, the diagnosis is more challenging. In addition to well-recognised causes of these complex neuropathies (eg, Friedreich's ataxia), next-generation sequencing (NGS) has identified an ever expanding number of causative genes. These include genes that were originally thought to cause other neurological syndromes (eg, Atlastin 1 was originally identified as causing hereditary spastic paraparesis but also causes $\mathrm{HSN}^{2}{ }^{3}$ ) and complex inherited diseases (such as Krabbe's disease) which can present with a CMT-like neuropathy, and in which the neuropathy may remain as the only manifestation of the disease. ${ }^{4}$
This review aims to provide a comprehensive list of the complex inherited neuropathy syndromes and an approach to diagnosis that is based on the major clinical features, for example, ataxia plus neuropathy or spasticity plus neuropathy as a pragmatic framework for clinical practice. While aimed at adult neurologists, this review includes some childhood diseases, including forme frustes that have adult presentations, such as recessive mutations in IGHMBP2, which cause spinal muscular atrophy with respiratory distress (usually a fatal childhood disease), but can cause adult-onset-recessive CMT2.

\section{Comprehensive disease list generation}

To identify complex inherited diseases associated with a peripheral neuropathy, we compiled the authors' lists and performed a PubMed search (in September 2016) for all publications describing a syndromic inherited neuropathy. The following search syntax was used: ('peripheral neuropathy') AND ('inherit"' OR 'genetic') NOT ('Charcot Marie Tooth'). All papers which described an inherited neuropathy in conjunction with other clinical features were included. For each condition identified in the search, the presence of a neuropathy was confirmed by reviewing the original clinical description and neurophysiology. Multiple reviews exist, including our recent review, for the 'pure' neuropathies, ${ }^{1}$ that is, CMT and related disorders so these will not be covered except for selected cases that we feel are more appropriately classified as a complex inherited neuropathy syndrome.

\section{A clinically based approach to the complex inherited neuropathy syndromes}

Even knowing where to start in the diagnostic evaluation of a patient with a complex inherited neuropathy syndrome can feel daunting. This is in part due to the large number of potentially causative genes but also to the rarity of these diseases, some of which are so rare (as small as single families) that even an experienced clinician is unlikely to have encountered them. The situation is further complicated by the fact that the neuropathy can be a major feature of the syndrome or largely masked by other clinical features. In this review, we included all inherited syndromes in which neuropathy has been described even if it is only a minor feature and present in a minority of patients (eg, SPG3A due to dominant mutations in Atlastin $1^{2}$ ). This is because 


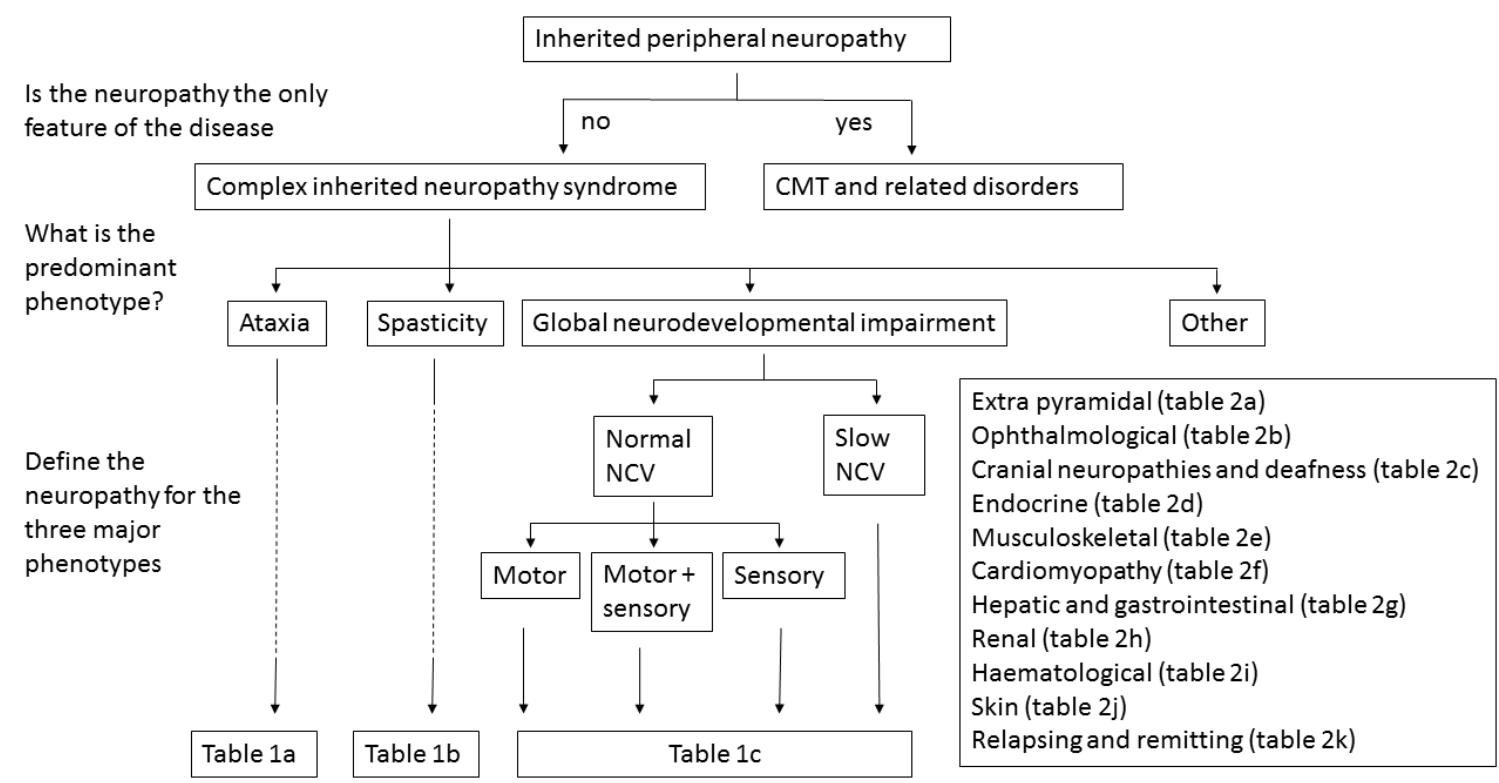

Figure 1 A diagnostic approach for patients with complex inherited neuropathy syndromes. The first step is to decide if the neuropathy is the sole feature of the disease, that is, Charcot-Marie-Tooth disease or the related disorders, hereditary motor neuropathy and hereditary sensory neuropathy or if it is part of a more complex syndrome. In patients in whom there are additional features, the majority will fall into one of the three major categories, ataxia, spasticity or global neurodevelopmental delay. Further classification is based on the features of the neuropathy and the reader is directed to the appropriate table for the list of possible disease genes. A proportion of patients will not fall into one of these three categories ('other') and in this scenario, further classification is based on additional clinical features, for example, extrapyramidal disease, and the reader is directed to the appropriate table for a list of disease genes. $\mathrm{NCV}$, nerve conduction velocity.

the most prominent phenotype of a syndrome may vary for a particular genetic condition. For example, in a patient with Friedreich's ataxia, a sensory neuropathy may be the main presenting feature whereas in others it may be a cerebellar ataxia. Having identified 157 complex inherited diseases with a neuropathy, we addressed the following four questions.

1. What is the predominant neurological phenotype?

2. Is the neuropathy predominantly motor or sensory and is the neuropathy clearly axonal or are the conduction velocities slow?

3. What are the other neurological and non-neurological features of the disease?

4. Is the disease treatable?

This strategy allowed us to develop a diagnostic approach based on the identification of the predominant phenotype (see figure 1). For the majority of conditions, this can be divided into the following three major neuropathy associated categories: (1) ataxia, (2) spasticity and (3) global neurodevelopmental impairment. For the complex neuropathy syndromes that do not fall easily into one of these three categories, we used 11 other phenotypic categories: (1) extrapyramidal features, (2) ophthalmic disease, (3) cranial neuropathies and deafness, (4) endocrinopathy, (5) musculoskeletal disease/myopathy, (6) cardiomyopathy, (7) hepatic and gastrointestinal (GI) disease, (8) renal failure, (9) haematological and immunological diseases and (10) skin and connective tissue features. We also include a separate category of complex inherited relapsing neuropathy syndromes, some of which may mimic Guillain-Barré syndrome. This is an important group of diseases as many have a metabolic aetiology and are often treatable if identified early in the disease course.

The introduction of NGS (either whole-genome, wholeexome or gene-specific panels) into clinical practice offers great promise for diagnosing complex inherited neuropathy syndromes. ${ }^{6}$ The ability to sequence all known disease genes
( $>150$ genes can cause a neuropathy as part of a complex inherited syndrome and almost 100 additional genes cause a form of CMT), however, is not a panacea for diagnosing this group of patients. The challenge, therefore, is the interpretation of the large number of novel variants identified in known disease genes for each individual. Knowing the phenotypes of the inherited complex neuropathy syndromes is one key to interpreting these variants. Because the prognosis of rare, treatable complex inherited neuropathy syndromes depends on early diagnosis, we have priorised these diseases.

The cost of NGS in the form of disease-specific panels is often cheaper than targeted Sanger sequencing of individual genes. We therefore recommend proceeding to disease-specific panels (eg, ataxia, spasticity, developmental delay) in the first instance. The only exception is for the ataxia and neuropathy syndromes where we recommend targeted testing for repeat expansion diseases first in cases with an appropriate phenotype (eg, Friedreich's ataxia, FXTAS, SCA1, 2, 3, 10, 12). With advances in NGS, it is likely that disease- specific panels will eventually be able to reliably detect repeat expansions.

\section{Major complex inherited neuropathy categories}

Ataxia and neuropathy syndromes (table 1a)

In the diagnostic evaluation of patients with neuropathy and cerebellar ataxia, we propose an initial screen for treatable causes followed by categorisation into whether the neuropathy is sensory and motor, predominantly motor or predominantly sensory as well as those with slow nerve conduction velocities (SNCV) (less than acceptable for axonal loss). Patients without an obvious initial diagnosis and a neuropathy with either normal or slow conduction velocities should have blood levels of phytanic and pristanic acid (Refsum's disease may be treated with dietary modification and plasma exchange ${ }^{7}$ ) as well as very long chain 
Table 1 A summary of the complex inherited neuropathy syndromes with one of the three major core clinical phenotypes of ataxia, spasticity or global neurodevelopmental impairment

\section{Disease \\ (Online Mendelian Inheritance \\ in Man (OMIM))}

Inheritance

Gene

Clinical description

(a) Ataxia and neuropathy syndromes

Ataxia and sensory predominant axonal neuropathy

Friedreich's ataxia/ FRDA-1 (229300) AR
$\mathrm{EAOH}$

(208920)

SCAR1 (606002)

Ataxia-telangiectasia (208900)

AR

ATM

\begin{abstract}
Abetalipoproteinemia (200100)
Ataxia with isolated vitamin $\mathrm{E}$ deficiency

(277460)
\end{abstract}

AR

MTP

AR

TTPA

Fragile $\mathrm{X}$ tremor ataxia syndrome (300623)

SCA27 (609307)

Galactosialidosis

(256540)

CANVAS (614575)

Unknown

FXTAS(repeat)

$A D$

AR

APTX

SETX

FGF14

CTSA
FXN (repeat)

Ataxia and sensory-motor axonal neuropathy

Leukoencephalopathy with brainstem and

spinal cord involvement (LBSL) (611105)

Neuropathy, ataxia, retinitis pigmentosa (NARP) (551500)

SCAN1

(607250)

Peroxisome biogenesis disorder 6A (214100) AR

m8618insTm8993T>G m8993T >C m9185T>C

AR

$A R$

Microcephaly, seizures, and developmental AR delay (MCSZ) (613402)

SCA1 (164400)

SCA3/MJD (109150)

SCA12 (604326)

SCA23 (610245)

Spinocerebellar ataxia, autosomal-recessive

21 (SCAR21) (607982)
$A D$

$A D$

$A D$

$A D$

$A D$

AR

\section{$A D$}

AR

AD

(repeat)

PPP2R2B (repeat)

PDYN

SCYL1
Early-onset ataxia, cardiomyopathy, myelopathy, optic atrophy, sensory axonal neuropathy

Early-onset ataxia, sensory axonal neuropathy, oculomotor apraxia, hypoalbuminemia (EAOH)

Juvenile onset ataxia, increased $\alpha$-fetoprotein, nystagmus, cerebellar and pontine atrophy, oculomotor apraxia, sensory axonal neuropathy

Childhood-onset progressive ataxia, conjunctival telangiectasia, sensory axonal neuropathy, chorea and dystonia, immunodeficiency and increased risk of malignancy, elevated $\alpha$-fetoprotein

Young onset; hypocholesterloaemia leading to malabsorption of fat-soluble vitamins (vitamin E), acanthocytes, retinitis pigmentosa, progressive sensory axonal neuropathy

Early-onset ataxia and sensory axonal neuropathy similar to Friedreich's ataxia, head titubation, normal fat absorption unlike abetalipoproteinemia, rarely retinitis pigmentosa Late-onset tremor, ataxia, parkinsonism, sensory axonal neuropathy, middle cerebellar peduncle changes on MR

Learning difficulties, cerebellar ataxia, sensory axonal neuropathy

Coarse facies, dwarfism, hearing loss, cherry red macular spot, global developmental delay, ataxia, haemangiomas, vascular abnormalities, rarely sensory axonal neuropathy Late-onset Cerebellar Ataxia, Sensory axonal neuropathy, Vestibular Areflexia Syndrome (CANVAS)

Slowly progressive spasticity, ataxia and dorsal column dysfunction, sensory-motor axonal neuropathy, characteristic MRI findings

Ataxia, retinitis pigmentosa, cardiomyopathy, sensory-motor axonal neuropathy

Cerebellar ataxia and sensory-motor axonal neuropathy

Failure to thrive, facial dimorphism, agenesis of the corpus callosum, death in first year of life, axonal motor neuropathy, progressive ataxia and sensory-motor axonal neuropathy in adulthood described

Microcephaly, global developmental delay, progressive cerebellar ataxia and atrophy, sensory-motor axonal neuropathy

Adult-onset, cerebellar ataxia, spasticity, sensory-motor axonal neuropathy in $40 \%$, occasional choreiform movements

Adult-onset, cerebellar ataxia, external ophthalmoplegia, spasticity, extrapyramidal, sensory-motor axonal neuropathy in $50 \%$

Adult-onset, cerebellar ataxia, pigmentary macular degeneration, sensory-motor axonal neuropathy

Adult-onset cerebellar ataxia, sensory-motor axonal neuropathy

Adult-onset cerebellar ataxia, tremor of head and arms, subclinical sensory-motor axonal neuropathy

Cerebellar ataxia, sensory-motor axonal neuropathy

Early-onset ataxia ( $<1$ year) with recurrent episodes of liver failure, sensory-motor axonal neuropathy, cerebellar atrophy 


\begin{tabular}{|c|c|c|c|}
\hline $\begin{array}{l}\text { Disease } \\
\text { (Online Mendelian Inheritance } \\
\text { in Man (OMIM)) }\end{array}$ & Inheritance & Gene & Clinical description \\
\hline \multicolumn{4}{|l|}{ Ataxia and motor predominant axonal neuropathy } \\
\hline SCA2 (183090) & $A D$ & ATXN2 (repeat) & $\begin{array}{l}\text { Adult-onset, slow saccades, ataxia, tremor, parkinsonism, } \\
\text { motor }>\text { sensory axonal neuropathy in } 80 \%\end{array}$ \\
\hline SCA36 (614153) & $A D$ & NOP56 & $\begin{array}{l}\text { Late-adult-onset gait ataxia, tongue atrophy and } \\
\text { fasciculation, distal motor neuropathy }\end{array}$ \\
\hline \multicolumn{4}{|l|}{ Ataxia and slow nerve conduction velocity (SNCV) } \\
\hline $\begin{array}{l}\text { Polyneuropathy, hearing loss, ataxia, retinitis } \\
\text { pigmentosa and cataracts (PHARC) (612674) }\end{array}$ & AR & $A B H D 12$ & $\begin{array}{l}\text { Onset second decade, neuropathy with SNCV, sensory } \\
\text { neuronal hearing loss, retinitis pigmentosa, spastic } \\
\text { paraplegia, ataxia }\end{array}$ \\
\hline $\begin{array}{l}\text { ARSACS } \\
(270550)\end{array}$ & AR & SACS & $\begin{array}{l}\text { Complex neurodegenerative disorder characterised by ataxia, } \\
\text { spasticity, neuropathy with SNCV }\end{array}$ \\
\hline $\begin{array}{l}\text { Ataxia, combined cerebellar and peripheral, } \\
\text { with hearing loss and diabetes mellitus } \\
\text { ACPHD (616192) }\end{array}$ & AR & DNAJC3 & $\begin{array}{l}\text { Cerebellar ataxia, neuropathy with SNCV, hearing loss, } \\
\text { diabetes mellitus }\end{array}$ \\
\hline $\begin{array}{l}\text { Cerebrotendinous xanthomatosis } \\
(213700)\end{array}$ & AR & CRP27A1 & $\begin{array}{l}\text { Adolescent-onset progressive ataxia, myelopathy and } \\
\text { dementia, cataracts, low cholesterol, atherosclerosis, } \\
\text { xanthomas, soft palate myoclonus, intractable infantile- } \\
\text { onset diarrhoea, cerebral white matter lesions on MRI, } \\
\text { sensory>motor axonal neuropathy, SNCV described in a } \\
\text { minority of patients }\end{array}$ \\
\hline Refsum's disease (266500) & AR & PHYH & $\begin{array}{l}\text { Sensory-motor neuropathy with normal or SNCV, deafness, } \\
\text { retinitis pigmentosa, ichthyosis, heart failure, ataxia, raised } \\
\text { CSF protein }\end{array}$ \\
\hline
\end{tabular}

(b) Spasticity and neuropathy syndromes

\section{Spasticity and sensory-predominant axonal neuropathy}

HSN with spastic paraplegia (256840)

SPG61 (615685)

$\begin{array}{ll}\text { AR } & \text { CCT5 } \\ \text { AR } & \text { ARL6IP1 }\end{array}$

Spasticity and sensory-motor axonal neuropathy

SPOAN (609541) AR

SPG3A (182600)
SPG7 (607259)

SPG10 (604187)

SPG11 (604360)

\section{AR}

$A D$

AR

$A D$

AR
CSF protein

Adult-onset, slow saccades, ataxia, tremor, parkinsonism,

Late-adult-onset gait ataxia, tongue atrophy and neuronal hearing loss, retinitis pigmentosa, spastic paraplegia, ataxia

Cerebellar ataxia, neuropathy with SNCV, hearing loss,

Adolescent-onset progressive ataxia, myelopathy and dementia, cataracts, low cholesterol, atherosclerosis, sensory>motor axonal neuropathy, SNCV described in a Sensory-motor neuropathy with normal or SNCV, deafness,

\begin{tabular}{|c|c|c|c|}
\hline & & & \\
\hline SPG15 (270700) & AR & ZFYVE26 & As SPG11, but with pigmentary maculopathy \\
\hline SPG26 (609195) & AR & B4GALNT1 & $\begin{array}{l}\text { Spastic paraplegia, intellectual disability, ataxia, dystonia, } \\
\text { axonal sensory-motor neuropathy }\end{array}$ \\
\hline SPG28 (09340) & AR & DDHD1 & $\begin{array}{l}\text { Spastic paraplegia, occasionally cerebellar eye signs and } \\
\text { subclinical axonal neuropathy }\end{array}$ \\
\hline SPG30 (610357 & AR & KIF1A & $\begin{array}{l}\text { HSP with sensory-motor axonal neuropathy } \pm \text { cerebellar } \\
\text { signs }\end{array}$ \\
\hline SPG43 (615043) & $A R$ & C19orf12 & $\begin{array}{l}\text { Childhood-onset spastic paraplegia and sensory-motor } \\
\text { axonal neuropathy, NBIA with optic atrophy, extrapyramidal } \\
\text { signs }\end{array}$ \\
\hline SPG46 (614409) & AR & GBA2 & $\begin{array}{l}\text { Spastic paraplegia, cognitive decline, thin corpus callosum, } \\
\text { ataxia, cataracts, bulbar dysfunction, axonal sensory-motor } \\
\text { neuropathy }\end{array}$ \\
\hline SPG55 (615035) & AR & C12ORF65 & $\begin{array}{l}\text { Early-onset spastic paraplegia, optic atrophy, intellectual } \\
\text { impairment, axonal sensory-motor neuropathy }\end{array}$ \\
\hline SPG56 (615030) & $A R$ & CYP2U1 & $\begin{array}{l}\text { Onset first decade, spastic paraplegia, rarely dystonia and } \\
\text { cognitive impairment, subclinical sensory-motor axonal } \\
\text { neuropathy }\end{array}$ \\
\hline
\end{tabular}

Severe mutilating sensory neuropathy with spastic paraplegia Childhood-onset spastic paraplegia with mutilating, sensory>motor axonal neuropathy

Early-onset spastic paraplegia, congenital optic atrophy and axonal sensory-motor neuropathy

Early-onset spastic paraplegia, axonal sensory-motor neuropathy in some patients

Spastic paraplegia, optic atrophy, ataxia and sensory-motor axonal neuropathy in some patients

Adult onset; spastic paraplegia, axonal sensory-motor neuropathy, rarely parkinsonism and cognitive decline

Onset second decade, spastic paraplegia, intellectual disability and cognitive decline, thin corpus callosum, mild cerebellar eye signs, axonal sensory-motor neuropathy, parkinsonism and dystonia, pseudobulbar involvement , but with pigmentary maculopathy axonal sensory-motor neuropathy signs signs neuropathy impairment, axonal sensory-motor neuropathy

Onset first decade, spastic paraplegia, rarely dystonia and neuropathy

Childhood-onset spastic paraplegia, sensory-motor axonal Continued 


\begin{tabular}{|c|c|c|c|}
\hline $\begin{array}{l}\text { Disease } \\
\text { (Online Mendelian Inheritance } \\
\text { in Man (OMIM)) }\end{array}$ & Inheritance & Gene & Clinical description \\
\hline Spastic ataxia 5 & AR & AFG3L2 & $\begin{array}{l}\text { Early-onset spastic paraplegia, later myoclonic epilepsy, } \\
\text { sensory-motor axonal neuropathy, ataxia, dystonia }\end{array}$ \\
\hline $\begin{array}{l}\text { Adult polyglucosan body disease } \\
\text { (263570) }\end{array}$ & AR & GBE1 & $\begin{array}{l}\text { Late-onset, cognitive impairment, spasticity, sensory-motor } \\
\text { axonal neuropathy, bladder dysfunction, cerebellar and } \\
\text { extrapyramidal signs also seen, periventricular white matter } \\
\text { abnormalities on MRI }\end{array}$ \\
\hline \multicolumn{4}{|c|}{ Spasticity and motor predominant axonal neuropathy } \\
\hline $\begin{array}{l}\text { Spinal muscular atrophy, distal (DSMA2) } \\
\text { (605726) }\end{array}$ & AR & SIGMAR1 & $\begin{array}{l}\text { Spastic paraplegia, motor neuronopathy predominantly } \\
\text { affecting the extensor muscles of the upper limbs }\end{array}$ \\
\hline SPG4 (182601) & $A D$ & SPAST & $\begin{array}{l}\text { Infantile-onset and adult-onset spastic paraplegia, motor } \\
\text { axonal neuropathy in some patients }\end{array}$ \\
\hline SPG9A (601162)/ SPG9B (616586) & AD/AR & ALDH18A1 & $\begin{array}{l}\text { Adolescent-onset and adult-onset spastic paraplegia, } \\
\text { dysarthria and motor neuronopathy, cataracts, skeletal } \\
\text { abnormalities }\end{array}$ \\
\hline SPG12 (604805) & AD & RTN2 & $\begin{array}{l}\text { Spastic paraplegia, motor neuropathy seen with homozygous, } \\
\text { recessive mutations (MMR, AMR, personal observation) }\end{array}$ \\
\hline SPG17 (270685) & $A D$ & BSCL2 & Silver syndrome, spasticity, motor neuropathy in arms $>$ legs \\
\hline SPG20/Troyer syndrome (275900) & AR & SPG20 & $\begin{array}{l}\text { Spasticity, short stature, mental retardation, facial } \\
\text { dysmorphism, distal amyotrophy/motor neuropathy }\end{array}$ \\
\hline SPG39 (612020) & AR & PNPLA6 & $\begin{array}{l}\text { Childhood onset of slowly progressive spastic paraplegia; } \\
\text { progressive distal motor neuropathy beginning in early } \\
\text { through late adolescence }\end{array}$ \\
\hline \multicolumn{4}{|l|}{ Spasticity and SNCV } \\
\hline SPG5A (270800) & AR & CYP7B1 & $\begin{array}{l}\text { Childhood to adult-onset spastic paraplegia and bladder } \\
\text { dysfunction, periventricular white matter abnormalities on } \\
\text { MRI, one patient described with SNCV }\end{array}$ \\
\hline Adrenoleukodystrophy (300100) & X-linked & $A B C D 1$ & $\begin{array}{l}\text { Adrenomyeloneuropathy, spastic paraparesis, adrenal } \\
\text { insufficiency, axonal sensory-motor neuropathy, sphincter } \\
\text { disturbance }\end{array}$ \\
\hline $\begin{array}{l}\text { Alpha-methylacyl-CoA racemase deficiency } \\
\text { (AMACRD) 614307) }\end{array}$ & AR & $A M A C R$ & $\begin{array}{l}\text { Retinopathy, myelopathy, axonal or SNCV neuropathy, } \\
\text { elevated phytanic and pristanic acids }\end{array}$ \\
\hline \multicolumn{4}{|c|}{ (c) Global neurodevelopmental impairment and neuropathy syndromes } \\
\hline \multicolumn{4}{|c|}{ Global neurodevelopmental impairment and sensory predominant axonal neuropathy } \\
\hline Congenital insensitivity to pain & AR & CLTCL1 & $\begin{array}{l}\text { Congenital insensitivity to pain and severe global } \\
\text { developmental delay, dysmorphic, delayed myelination on } \\
\text { brain MRI }\end{array}$ \\
\hline $\begin{array}{l}\text { Familial dysautonomia, hereditary, sensory } \\
\text { autonomic neuropathy, with intellectual } \\
\text { disability }\end{array}$ & AR & TECPR2 & $\begin{array}{l}\text { Global developmental delay, sensory axonal neuropathy, } \\
\text { autonomic features, central apnoea/chronic respiratory } \\
\text { disease, seizures, encephalopathy }\end{array}$ \\
\hline $\begin{array}{l}\text { MTDPS7 } \\
(271245)\end{array}$ & AR & C10ORF2 & $\begin{array}{l}\text { Infantile-onset ataxia, PEO, encephalopathy, deafness, } \\
\text { seizures and sensory axonal neuropathy }\end{array}$ \\
\hline \multicolumn{4}{|c|}{ Global neurodevelopmental impairment and sensory-motor axonal neuropathy } \\
\hline Giant axonal neuropathy-1 (256850) & AR & GAN & $\begin{array}{l}\text { Progressive neurodegenerative disorder characterised by } \\
\text { spasticity ataxia and sensory-motor axonal neuropathy, } \\
\text { kinky/curly hair }\end{array}$ \\
\hline $\begin{array}{l}\text { Neurodegeneration with brain iron } \\
\text { accumulation } 2 A / \text { infantile neuroaxonal } \\
\text { dystrophy }(256600)\end{array}$ & AR & PLA2G6 & $\begin{array}{l}\text { Infantile-onset, progressive neurodegeneration (tetraplegia, } \\
\text { dementia, visual loss) and axonal sensory-motor neuropathy, } \\
\text { globus pallidus iron deposition on MRI }\end{array}$ \\
\hline CEDNIK syndrome (609528) & AR & SNAP29 & $\begin{array}{l}\text { Cerebral Dysgenesis and severe psychomotor retardation, } \\
\text { axonal sensory-motor Neuropathy, Ichthyosis, palmoplantar } \\
\text { Keratoderma, fatal by second decade of life }\end{array}$ \\
\hline $\begin{array}{l}\text { Pyruvate dehydrogenase E1-alpha deficiency } \\
\text { (PDHAD/312170) }\end{array}$ & X-linked & PDHA1 & $\begin{array}{l}\text { Episodic lactic acidosis, cerebellar ataxia, } \\
\text { neurodevelopmental delay and clinical features resembling } \\
\text { Leigh syndrome, neuropathy reported (NCV not reported) }\end{array}$ \\
\hline $\begin{array}{l}\text { Congenital disorder of deglycosylation } \\
(615273)\end{array}$ & AR & NGLY1 & $\begin{array}{l}\text { Developmental delay, choreoathetosis, alacrimia, seizures, } \\
\text { microcephaly, transaminitis, neuropathy }\end{array}$ \\
\hline $\begin{array}{l}\text { Hypomyelinating leukodystrophy } 6 \\
\text { (HLD6/612438) }\end{array}$ & $A D$ & TUBB4A & $\begin{array}{l}\text { Early-onset, delayed motor development, extrapyramidal } \\
\text { movement disorder, spasticity, ataxia, rarely seizures and } \\
\text { sensory-motor axonal neuropathy }\end{array}$ \\
\hline
\end{tabular}




\begin{tabular}{|c|c|c|c|}
\hline $\begin{array}{l}\text { Disease } \\
\text { (Online Mendelian Inheritance } \\
\text { in Man (OMIM)) }\end{array}$ & Inheritance & Gene & Clinical description \\
\hline Mental retardation 9 (601255) & $A D$ & KIF1A & $\begin{array}{l}\text { Developmental delay, microcephaly, seizures, extrapyramidal } \\
\text { disorder, spasticity, cerebellar atrophy, sensory-motor axonal } \\
\text { neuropathy }\end{array}$ \\
\hline PBD9B (614879) & AR & PEX7 & $\begin{array}{l}\text { Infantile (more severe) variant of Refsum's disease, skeletal } \\
\text { and facial dysmorphism, global developmental delay }\end{array}$ \\
\hline MTDPS5 (612073) & AR & SUCLA2 & $\begin{array}{l}\text { 'Leigh'-like syndrome, deafness, progressive dystonia, mild } \\
\text { methylmaolnic acidaemia }\end{array}$ \\
\hline \multicolumn{4}{|c|}{ Global neurodevelopmental impairment and motor predominant axonal neuropathy } \\
\hline $\begin{array}{l}\text { Hexosaminidase A deficiency } \\
\text { (272800) }\end{array}$ & AR & HEXA & $\begin{array}{l}\text { Usually infantile-onset, developmental delay and cognitive } \\
\text { decline, visual loss ('cherry red spot'), motor>sensory } \\
\text { neuronopathy, hypometric saccades, adult-onset (second } \\
\text { decade) cases described }\end{array}$ \\
\hline $\begin{array}{l}\text { Pontocerebellar hypoplasia type } 1 \text { B } \\
\text { (614678) }\end{array}$ & AR & EXOSC3 & $\begin{array}{l}\text { Severe disease often with death in first five years, } \\
\text { developmental delay, pontocerebellar hypoplasia on MRI, } \\
\text { motor neuronopathy }\end{array}$ \\
\hline $\begin{array}{l}\text { Pontocerebellar hypoplasia (PCH9) } \\
\text { (615809) }\end{array}$ & $A R$ & AMPD2 & $\begin{array}{l}\text { Global developmental delay, spasticity, seizures, dysmorphic } \\
\text { facies, axonal neuropathy, agenesis of the corpus callosum } \\
\text { and cerebellar hypoplasia on MRI }\end{array}$ \\
\hline $\begin{array}{l}\text { Spinal muscular atrophy, lower extremity } \\
\text { predominant (SMALED1) (158600) }\end{array}$ & $A D$ & DYNC1H1 & $\begin{array}{l}\text { Congenital-onset lower-limb motor neuronopathy with } \\
\text { contractures, global developmental delay and cerebral } \\
\text { dysgenesis in some patients }\end{array}$ \\
\hline $\begin{array}{l}\text { Spinal muscular atrophy, lower extremity } \\
\text { predominant (SMALED2) (615290) }\end{array}$ & $A D$ & $B I C D 2$ & $\begin{array}{l}\text { Congenital-onset lower-limb motor neuronopathy with } \\
\text { contractures, global developmental delay and cerebral } \\
\text { dysgenesis in some patients }\end{array}$ \\
\hline $\begin{array}{l}\text { Infantile-onset multisystem neurological, } \\
\text { endocrine and pancreatic disease }\end{array}$ & $A R$ & PTRH2 & $\begin{array}{l}\text { Infantile-onset multisystem disease with intellectual } \\
\text { disability, microcephaly, progressive ataxia, sensory neuronal } \\
\text { hearing loss, hepatomegaly, pancreatic insufficiency, } \\
\text { proximal placement of thumb, SNCV neuropathy }\end{array}$ \\
\hline MEDNIK (609313) & AR & AP1S1 & $\begin{array}{l}\text { Congenital-onset, Mental retardation, Enteropathy (severe } \\
\text { congenital diarrhoea), Deafness, sensory-motor Neuropathy } \\
\text { with intermediate conduction velocities, Ichthyosis, } \\
\text { Keratoderma }\end{array}$ \\
\hline Cockayne syndrome (216400/133540) & AR & ERCC6/ ERCC8 & $\begin{array}{l}\text { Dwarfism, optic atrophy, mental retardation, cutaneous } \\
\text { photosensitivity, pigmentary retinopathy, deafness, } \\
\text { neuropathy with slow conduction velocities }\end{array}$ \\
\hline Leigh syndrome variant (256000) & AR & SURF1 & $\begin{array}{l}\text { Leigh syndrome (early-onset progressive neurodegeneration } \\
\text { of the brain stem, basal ganglia and spinal cord), neuropathy } \\
\text { with SNCV }\end{array}$ \\
\hline $\begin{array}{l}\text { Encephalopathy due to defective } \\
\text { mitochondrial and peroxisomal fission } 2 \\
\text { (EMPF2) (617086) }\end{array}$ & AR & MFF & $\begin{array}{l}\text { Leigh-like syndrome, developmental delay, optic atrophy, } \\
\text { seizures, sensory-motor neuropathy with SNCV, Leigh } \\
\text { syndrome-like MRI brain (T2 high signal of basal ganglia and } \\
\text { subthalamic nucleus) }\end{array}$ \\
\hline $\begin{array}{l}\text { Agenesis of the corpus callosum with } \\
\text { peripheral neuropathy ( } 218000)\end{array}$ & AR & SLC12A6 & $\begin{array}{l}\text { Mental retardation and progressive neurodegeneration, } \\
\text { dysmorphic facies and facial diplegia, agenesis of the corpus } \\
\text { callosum, neuropathy with intermediate conduction velocities }\end{array}$ \\
\hline Aicardi-Goutieres syndrome & \multicolumn{2}{|c|}{$\begin{array}{l}\text { TREX1 (606609, AD/AR) RNASEH2A (606034), RNASEH2B (AR, } \\
\text { 610326), RNASEH2C (AR, 610330), SAMHD1 (AR, 606754), } \\
\text { ADAR1 (AR, 146920), IFH1 (AD, 606951) }\end{array}$} & $\begin{array}{l}\text { Inflammatory syndrome, encephalopathy and psychomotor } \\
\text { regression of utero or infantile onset, bilateral striatal } \\
\text { necrosis, leukodystrophy, intracranial calcifications, CSF } \\
\text { lymphocytosis, spastic paraparesis, rarely neuropathy with } \\
\text { SNCV }\end{array}$ \\
\hline
\end{tabular}




\begin{tabular}{|c|c|c|c|}
\hline $\begin{array}{l}\text { Disease } \\
\text { (Online Mendelian Inheritance } \\
\text { in Man (OMIM)) }\end{array}$ & Inheritance & Gene & Clinical description \\
\hline $\begin{array}{l}\text { Leukodystrophy hypomyelination and } \\
\text { congenital cataract (HLD5 HCC) (610532) }\end{array}$ & AR & FAM126A & $\begin{array}{l}\text { Congenital cataracts, global developmental delay from } 1 \text { year, } \\
\text { diffuse cerebral hypomyelination on MRI, neuropathy with } \\
\text { SNCV }\end{array}$ \\
\hline Metachromatic leukodystrophy (250100) & AR & ARSA & $\begin{array}{l}\text { Severe late infantile form with mental retardation and severe } \\
\text { course. Regression before } 30 \text { months; adult-onset, psychiatric } \\
\text { symptoms, leukodystrophy on MRI, progressive neuropathy } \\
\text { with SNCV, optic atrophy }\end{array}$ \\
\hline $\begin{array}{l}\text { Pelizaeus-Merzbacher disease (312080) } \\
\text { SPG2 (312920) }\end{array}$ & X-linked & PLP1 & $\begin{array}{l}\text { Infantile-onset, nystagmus, cognitive impairment, spasticity } \\
\text { and ataxia, leukodystrophy on MRI, mild multifocal SNCV } \\
\text { neuropathy seen with null mutations and more mild } \\
\text { phenotype of mild spasticity and ataxia }\end{array}$ \\
\hline
\end{tabular}

For the sake of brevity, some conditions, for example, ARSACS, that could be classified in more than one major phenotypic category, only appear once in this table with the additional core features outlined in the clinical description. Number in parenthesis is the OMIM phenotype number.

AD, autosomal dominant; AR, autosomal recessive; ARSACS, autosomal-recessive spastic ataxia of Charlevoix-Saguenay; CSF, cerebrospinal fluid; EAO, Early age of onset; FLAIR, Fluid-Attenuated Inversion Recovery; MTDPS, mitochondrial DNA depletion syndrome; NBIA, neurodegeneration with brain iron accumulation; OMIM, Online Mendelian Inheritance in Man; PEO, progressive external ophthalmoplegia; SCAN1, spinocerebellar ataxia autosomal recessive with axonal neuropathy; SCAR1, spinocerebellar ataxia autosomal-recessive 1; SNCV, slow nerve conduction velocities.

fatty acids and lysosomal enzymes measured (allogenic bone marrow transplantation may be effective in some peroxisomal and lysosomal storage diseases (eg, adrenoleukodystrophy) ${ }^{89}$ ). Vitamins E and B12, including methylmalonic acid and homocysteine (to screen for functional vitamin B12 deficiency), should be measured as deficiencies may cause an ataxia and neuropathy phenotype and may be treatable. ${ }^{10}$ Finally, although rare, plasma cholestanol for cerebrotendinous xanthomatosis is an important disease to identify early in the disease course as it is preventable with dietary modification and treatment with chenodeoxycholic acid. Clues to this diagnosis include the combination of diarrhoea, cataracts or infantile jaundice. ${ }^{11}$

Most patients with ataxia and a neuropathy will have an axonal neuropathy with normal nerve conduction velocities and reduced distal amplitudes. A motor-predominant axonal neuropathy or neuronopathy is rare in the ataxia neuropathy syndromes but is seen in SCA2 and SCA $36 .{ }^{12}$ SCA2 is a trinucleotide repeat disease and therefore may not be identified on NGS. Interestingly, an expansion size of between 30 and 35 repeats is associated with amyotrophic lateral sclerosis, ${ }^{13}$ whereas larger expansion sizes will cause a combined neuropathy, ataxia syndrome often with slow saccadic eye movements, tremor and occasionally an extrapyramidal disorder that may mimic multiple system atrophy. ${ }^{14}$ SCA36 presents as a late-adult-onset ataxic syndrome with a distal motor neuropathy and bulbar involvement. ${ }^{12}$ It is caused by a hexanucleotide expansion.

Ataxia and a sensory axonal neuropathy is the most common combination caused by recessive mutations in a variety of genes, usually with disease onset in the first decade. The sensory neuropathy may contribute to the manifestations of the ataxia. Friedreich's ataxia, due to a trinucleotide repeat expansion in the FDRA gene, is the most common form. ${ }^{15}$ Ataxia telangiectasia, early-onset ataxia with oculomotor apraxia and hypoalbuminemia (EAOH/aprataxin) and spinocerebellar ataxia, autosomal-recessive 1 (SCAR1/senataxin) may also cause a sensory ataxic neuropathy syndrome similar to Friedreich's ataxia often in association with a raised serum $\alpha$-fetoprotein level. Distinguishing clinical features include the presence of cardiomyopathy in Friedreich's ataxia, 'oculomotor apraxia' in EAOH and SCAR1 and chorea, conjunctival telangiectasia and the susceptibility to infections and malignancies in ataxia telangiectasia. $^{15}$

The autosomal-dominant SCAs 1, 3, 7, 10 and 12 may all cause a sensory and motor axonal neuropathy. They are all due to repeat expansions and may therefore require targeted genetic testing. Phenotypic clues to the individual SCAs include extrapyramidal signs and ophthalmoplegia in SCA3, ${ }^{16}$ pigmentary macular degeneration in SCA7 and prominent tremor in SCA12. ${ }^{17} 18$

A neuropathy with SNCV is rare in patients with an ataxia neuropathy syndrome. The most common by far is autosomal-recessive spastic ataxia of Charlevoix-Saguenay (ARSACS) due to recessive mutations in the SACS gene, which encodes the molecular chaperone protein, DNAJC29. ${ }^{19}$ Neuropathy may be the presenting issue and the most prominent clinical finding (see online supplementary file 1 for an example of the neurophysiology). ${ }^{19}$ In addition to ataxia and a neuropathy, patients may develop a myelopathy and in rare cases seizures. Ataxia, combined peripheral and cerebellar, with hearing loss and diabetes mellitus (APCHD), due to recessive mutations in another heat shock protein DNAJC3, may also cause an SNCV neuropathy. ${ }^{20}$ Finally, polyneuropathy, hearing loss, ataxia, retinitis pigmentosa and cataracts (PHARC) syndrome is also a rare cause. $^{21}$

Further diagnostic clues can be obtained by MRI of the brain. This may identify white matter changes that are highly suggestive of specific diagnoses for some ataxia neuropathy syndromeshigh signal of the deep white matter tracts of the brain and dorsal 

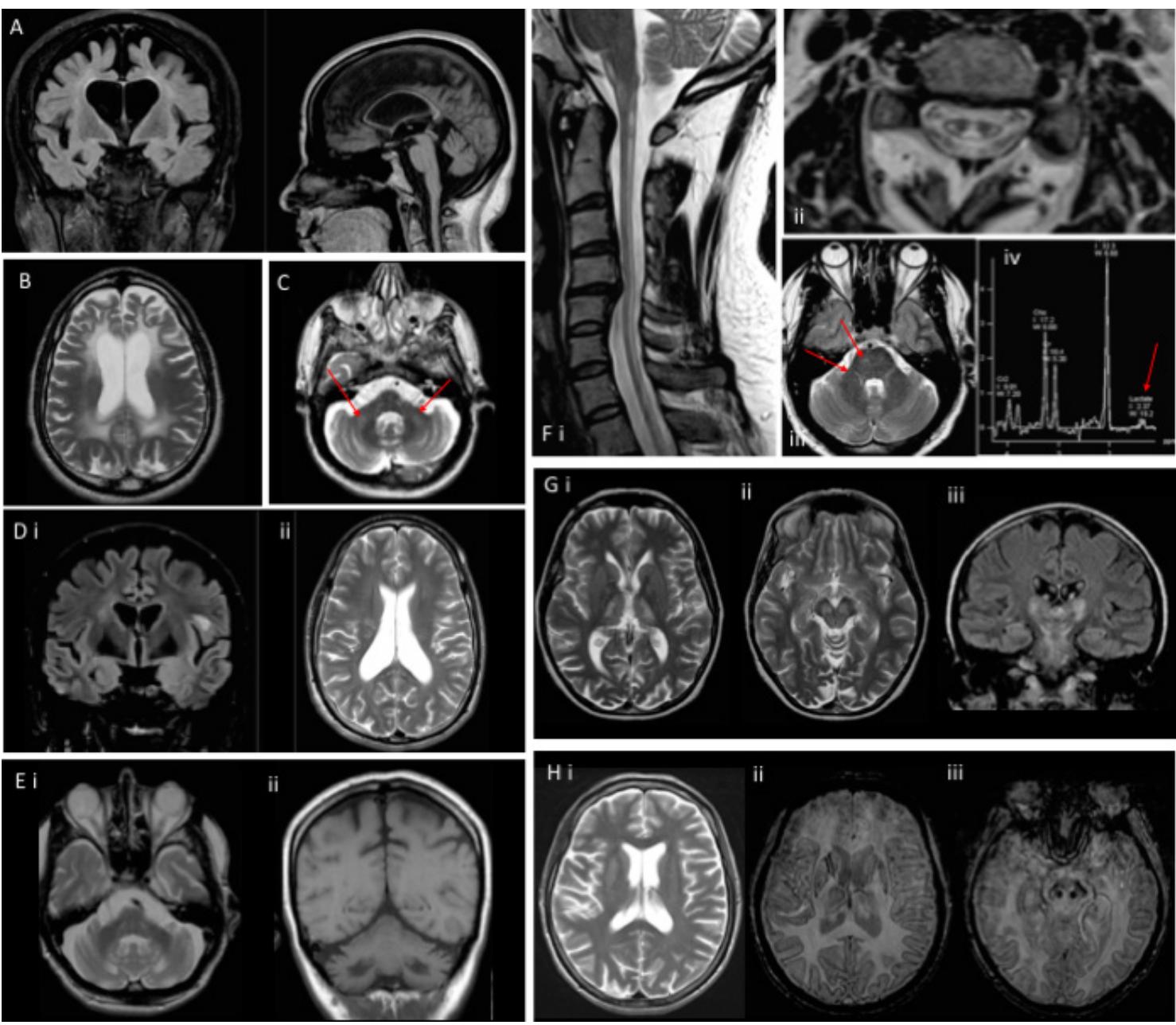

Figure 2 Examples of central nervous system MRI that may assist in the diagnostic evaluation of patients with peripheral neuropathy as part of a complex inherited disease. (Ai) shows coronal Fluid-attenuated Inversion Recovery (FLAIR) and (Aii) sagittal T1w images from a patient with SPG 11 demonstrating a thin corpus callosum and cerebellar hypoplasia. (B) shows an axial T2w image of a patient with metachromatic leukodystrophy in which there is bilateral confluent white matter signal abnormality with cerebral volume loss. (C) is an axial T2w image from a patient with fragile X tremor ataxia syndrome and demonstrates bilateral signal change in the cerebellar peduncle (arrows) and pontine, peduncular and cerebellar volume loss. (D) shows coronal FLAIR (Di) and axial T2w (Dii) images from a patient with adult-onset polyglycosan body disease demonstrating multifocal cerebral white matter lesions. (E) shows axial T2w (Ei) and coronal T1w (Eii) images from a patient with cerebrotendinous xanthomatosis demonstrating symmetrical signal change involving the peridentate white matter of both cerebellar hemispheres. (F) shows a selection of images from a patient with leukoencephalopathy with brainstem and spinal cord involvement and raised lactate. (Fi) and (Fii) are sagittal and axial images of the cervical cord demonstrating longitudinally extensive T2 hyperintense signal change involving the dorsal and lateral columns. The characteristic brainstem signal change (red arrows) in an axial T2w image is shown in (Fiii). (Fiv) shows the small lactate peak (red arrow) detected using localised 1 hour magnetic resonance spectroscopy. (G) shows axial T2w (Gi and Gii) and coronal FLAIR (Giii) images from a patient with Krabbe disease. The images show signal change involving the long tracts and deep grey matter. (H) shows axial T2w (Hi) and susceptibility weighted (SWI) (Hii and Hiii) images from a patient with neurodegeneration and brain iron accumulation. Although the T2w image looks normal, the SWI images show increased susceptibility from abnormal mineralisation in the superficial and deep cortical grey matter.

columns and lateral corticospinal tracts due to recessive DARS2 mutations, ${ }^{22} \mathrm{~T} 2$ high signal of the middle cerebellar peduncles in Fragile $\mathrm{X}$ tremor ataxia syndrome $\mathrm{e}^{23}$ and white matter signal abnormalities and bilateral dentate nuclei lesions of the cerebellum in cerebrotendinous xanthomatosis ${ }^{24}$ (see figure 2).

Spasticity and neuropathy syndromes (table $1 \mathrm{~b}$ )

The initial diagnostic evaluation of patients with spastic neuropathy syndromes without an obvious cause should include measurement of vitamin B12, methylmalonic acid and folate, phytanic and pristanic acid (alpha-methylacyl-CoA racemase deficiency (AMACR)), very long chain fatty acids and lysosomal enzymes. In addition, one should have a low threshold for performing MRI of the spinal cord to find a structural cause of myelopathy.

After screening for treatable spastic neuropathy syndromes, we suggest that the next step is to define the underlying neuropathy. Unlike the neuropathy ataxia syndromes, a motor axonal neuropathy is a feature of some hereditary spastic paraplegias (HSP) which may present as either an HSP or distal HMN. In SPG20 (Troyer syndrome), a distal motor neuropathy is seen in combination with spasticity, short stature and learning difficulties. ${ }^{25}$ SPG9A and SPG9B are also characterised by spastic paraplegia, learning difficulties and a distal motor neuropathy in addition to cataracts and skeletal abnormalities. ${ }^{26}$ SPG17 (Silver syndrome) is an autosomal-dominant disorder due to BSCL2 
mutations and is a relatively common cause of HSP and distal motor neuropathy predominantly affecting the upper limbs. ${ }^{27}$ Distal spinal muscular atrophy type 2 (DSMA2), due to recessive mutations in SIGMAR1, causes a similar phenotype but preferentially affecting the extensor muscles of the forearm. ${ }^{28}$ The combination of motor neuropathy and spastic paraplegia has also been reported in SPG39 $9^{29}$ and SPG12 (MMR and AMR personal observation in a recessive case).

SPG10 is a more common cause of spasticity and a mixed motor and sensory axonal neuropathy and may be complicated by cognitive decline and parkinsonism. ${ }^{30}$

A pure sensory axonal neuropathy and spasticity is less common but in combination with an ulceromutilating phenotype suggests mutations in CCT5 (HSN with spastic paraplegia), ${ }^{31}$ ARL6IP1 (SPG61) and rarely ATL1 (SPG3A). ${ }^{3} 32$

A neuropathy with SNCV in association with spasticity is also rare but reported in ARSACS and PHARC syndrome (see ataxia neuropathy section). ${ }^{2133}$ In addition, SNCV have been described in the neuropathy associated with the peroxisomal disorder, AMACR. $^{34}$

Bladder involvement, which is probably not uncommon in many kinds of HSPs, may be a prominent feature of adult polyglycosan body disease, ${ }^{35}$ adrenomyeloneuropathy and SPG5A. ${ }^{3637}$

MRI of the brain can provide important diagnostic clues (see figure 2). Periventricular white matter lesions suggestive of multiple sclerosis may be seen in adult-onset polyglycosan body disease and SPG5A. ${ }^{35} 36$ Some cases of neurodegeneration with brain iron accumulation diseases may present as a spasticity neuropathy syndrome (eg, mutations in PLA2G6, C19orf12/ SPG43); MRI shows iron deposition in the basal ganglia. ${ }^{38} 39$ Finally, a group of recessive spastic paraplegia genes associated with a thin corpus callosum on MRI have recently been identified as a cause of neuropathy spasticity syndromes. SPG11 is the most common of these syndromes and presents with spastic paraplegia, cognitive decline, sensory and motor axonal neuropathy and often weight gain ${ }^{40}$; patients with SPG15 have a similar phenotype but with pigmentary maculopathy ${ }^{41}$; SPG46 is a similar disease to SPG11 but with cataracts. ${ }^{42}$

Global neurodevelopmental impairment and neuropathy syndromes (table 1c)

Achieving a diagnosis is more difficult in this phenotypic category. Most are rare. Characterising the phenotype may be challenging as there is a broad range of phenotypes including spasticity, ataxia, cardiomyopathy, endocrine and GI dysfunction and dermatological manifestations, further complicated by developmental delay. Nevertheless, with the advent of NGS, it is likely that milder forms of these diseases will be described and an awareness of the key clinical features may assist in diagnosis. Few are currently treatable, but screening for metachromatic leukodystrophy and Krabbe disease is recommended as both may be treatable disorders. In addition, there are clinical trials for Aicardi-Goutieres syndrome and giant axonal neuropathy (ClinicalTrials.gov identifier NCT02362453 and NCT02362438).

As for the spastic and ataxic neuropathy syndromes, defining the type of neuropathy can be helpful in achieving a genetic diagnosis. A pure motor axonal neuropathy as part of a complex neurodevelopmental syndrome is seen with mutations in DYNC1H1 and BICD2. ${ }^{434}$ The two conditions are almost identical and can present as arthrogryposis predominantly affecting the lower limbs. Other causes of a motor neuropathy/neuronopathy in this group include pontocerebellar hypoplasia type $1 \mathrm{~B}$ and hexosaminidase $\mathrm{A}$ and B deficiency. ${ }^{45} 46$
Global developmental delay is a relatively common finding in several of the congenital insensitivity to pain syndromes (eg, recessive CTLCL1 mutations ${ }^{47}$ ), although in some cases the sensory nerve conduction studies may be normal despite significant ulceromutilation as is seen with recessive loss-of-function SCN9A mutations. ${ }^{48}$ Recessive mutations in TECPR2 are a rare cause of a sensory and autonomic neuropathy with global developmental delay, in which patients also experience chronic respiratory disease, apnoeas and seizures. ${ }^{49}$

A peripheral neuropathy with SNCV is a more common finding among this group of diseases and includes the lysosomal storage diseases metachromatic leukodystrophy and Krabbe disease. Other causes include HLD5 (leukodystrophy, hypomyelination and congenital cataracts) ${ }^{50}$ congenital disorders of glycosylation (recessive PMM2 mutations), ${ }^{51}$ Andermann's syndrome (agenesis of the corpus callosum and peripheral neuropathy), ${ }^{52}$ Cockayne syndrome, ${ }^{53}$ Leigh's syndrome due to SURF1 and MFF mutations, ${ }^{54} 55$ the complex infantile-onset IMNEPD (complex neurodegeneration in the context of hearing loss and pancreatic insufficiency) ${ }^{56}$ and Aicardi-Goutières syndrome which is an inflammatory disease that presents as an inflammatory syndrome and may respond partially to immunosuppression. ${ }^{57}$

MRI of the brain can be useful for directing genetic investigations in this group of patients (see figure 2). The detection of a leukodystrophy is seen in many of the lysosomal storage disorders and in metachromatic leukodystrophy, if characteristic, should prompt further investigations in the face of low normal aryl sulfatase activity to ensure that a sulfatide activator protein deficiency is not missed. ${ }^{58}$ Other diseases associated with white matter findings pointing to a possible leukodystrophy include Krabbe disease, congenital disorders of glycosylation, HLD5, giant axonal neuropathy and Aicardi-Goutières syndrome. ${ }^{50} 5159$

Other MRI findings may also provide clues to the genetic aetiology-agenesis of the corpus callosum in Andermann's syndrome, ${ }^{52}$ cerebral dysgenesis in the severe cerebral dysgenesis, neuropathy, ichthyosis and palmoplantar keratoderma (CEDNIK) syndrome, ${ }^{60}$ pontocerebellar hypoplasia in $\mathrm{PCH} 1 \mathrm{~B}$ and 9 (where it is also associated with agenesis of the corpus callosum) ${ }^{\mathrm{w} 61 \mathrm{w} 62}$ and iron deposition in NB12A due to PLA2G6 ${ }^{38}$ mutations, and striatal necrosis in Aicardi-Goutières syndrome. ${ }^{57}$

\section{Other complex inherited neuropathy categories}

Extrapyramidal disease and neuropathy syndromes (table 2a)

Peripheral neuropathy is a rare association with extrapyramidal disease and is most commonly seen in the context of mitochondrial disease due to either nuclear or mitochondrial DNA mutations. The classical SANDO syndrome of sensory axonal neuropathy, dysarthria and ophthalmoplegia can be associated with parkinsonism. ${ }^{\text {w63 }}$ Chorea and dystonia in the context of a motor predominant neuropathy is seen with both Chorea acanthocytosis and McLeod's syndrome. ${ }^{\text {w64 }}$ Finally, recessive mutations in HSJ1 and both dominant and recessive mutations in LRSAM1 (proteins involved in the ubiquitin proteosome system) present with late-onset CMT2 but may develop Parkinson's disease later in life. ${ }^{\text {w65 w66 }}$

\section{Ophthalmological and neuropathy syndromes (table 2b)}

Performing a thorough ophthalmological examination to detect external ophthalmoparesis, optic atrophy, retinitis pigmentosa and cataracts can be useful in refining the potential genetic diagnosis of a complex inherited neuropathy syndrome.

The combination of severe optic atrophy and a mild and predominantly sensory axonal neuropathy is suggestive of 
Table 2 A summary of the complex inherited neuropathy syndromes with one of the minor 10 clinical phenotypes associated with neuropathy

\begin{tabular}{|c|c|c|c|}
\hline Disease (OMIM) & Inheritance & Gene & Clinical description \\
\hline \multicolumn{4}{|c|}{ (a) Extrapyramidal disease and neuropathy syndromes } \\
\hline $\begin{array}{l}\text { Leukoencephalopathy with dystonia and motor } \\
\text { neuropathy (613724) }\end{array}$ & AR & $S C P 2$ & $\begin{array}{l}\text { Dystonia, hyposmia, azoospermia, motor predominant axonal } \\
\text { neuropathy, bilateral thalamic T2 high signal on MRI }\end{array}$ \\
\hline MTDPS4B (613662) & AR & POLG & $\begin{array}{l}\text { SANDO: Sensory Axonal Neuropathy, Dysarthria, } \\
\text { Ophthalmoplegia, also parkinsonism and deafness. Also } \\
\text { caused by recessive C10orf2 mutations }\end{array}$ \\
\hline $\begin{array}{l}\text { Chorea acanthocytosis } \\
\text { (200150) }\end{array}$ & AR & VPS13A & $\begin{array}{l}\text { Onset third to fifth decade, red cell acanthocytosis and } \\
\text { progressive neurodegeneration, seizures, dysarthria, chorea, } \\
\text { orofacial dyskinesia, psychiatric disturbance, axonal sensory- } \\
\text { motor neuropathy, raised CK }\end{array}$ \\
\hline McLeod syndrome (300842) & $\mathrm{XL}$ & $X K$ & $\begin{array}{l}\text { Onset } 25-60 \text {, acanthocytes and Huntington-like syndrome, } \\
\text { also epilepsy, cardiomyopathy, axonal motor neuropathy. }\end{array}$ \\
\hline CMT2P (614436) & $A D / A R$ & LRSAM1 & $\begin{array}{l}\text { Onset third to eighth decade. Late-onset parkinsonism } \\
\text { described }\end{array}$ \\
\hline DSMA 5 (614881) & AR & HSJ1 & $\begin{array}{l}\text { Onset second decade, motor predominant axonal } \\
\text { neuropathy, rarely late-onset parkinsonism }\end{array}$ \\
\hline Mitochondrial disease & $\mathrm{m} 1095 \mathrm{~T}>\mathrm{C}$ & MTRNR1 (561000) & $\begin{array}{l}\text { Parkinsonism, deafness and sensory-motor axonal } \\
\text { neuropathy }\end{array}$ \\
\hline SPG10 (604187) & $A D$ & KIF5A & See table $1 \mathrm{~b}$ \\
\hline MTDPS5 (612073) & AR & SUCLA2 & See table 1c \\
\hline
\end{tabular}

(b) Ophthalmological and neuropathy syndromes

Optic atrophy and neuropathy syndromes

Syndromic optic atrophy (125250)

Costeff syndrome or OPA3-related

$A D$

AR/AD

OPA1

OPA3

3-methylglutaconic aciduria (258501)

Optic atrophy and cataracts (165300)

Leber optic atrophy $(53500)$

Mitochondria

MT-ND1, ND4, ND6

HMSN6B

AR

(616505)

$\begin{array}{ll}\text { CMTX5 (311070) } & \text { X-lin } \\ \text { BVVLS2 } & \text { AR } \\ \text { (614707) }\end{array}$

$\begin{array}{ll}\text { X-linked } & \text { PRPS1 } \\ \text { AR } & \text { SLC52A2 }\end{array}$

\begin{tabular}{|c|}
\hline SPOAN (609541) \\
\hline SPG7 (607259) \\
\hline SPG43 (615043) \\
\hline SPG55 (615035) \\
\hline SPG57 (615658) \\
\hline Metachromatic leukodystrophy (250100) \\
\hline Krabbe disease (245200) \\
\hline EMPF2 (617086) \\
\hline Cockayne syndrome (216400/133540) \\
\hline $\begin{array}{l}\text { Hexosaminidase A deficiency } \\
(272800)\end{array}$ \\
\hline
\end{tabular}

\section{Sandhoff disease}

(268800)

HAYOS (617183)

Retinitis pigmentosa and neuropathy syndromes

Methylmalonic aciduria and homocystinuria type Cb1c (MMACHC) (277400)

\begin{tabular}{l} 
Kearns-Sayre syndrome (530000) \\
Posterior column ataxia and retinitis \\
pigmentosa (PCARP/6 09033) \\
\hline NARP (551500) \\
\hline Refsum's disease (266500) \\
\hline PHARC syndrome (612674) \\
\hline
\end{tabular}

\begin{tabular}{lll} 
AR & KLC2 & See table $1 \mathrm{~b}$ \\
AR & PGN & See table $1 \mathrm{~b}$ \\
AR & C19orf12 & See table $1 \mathrm{~b}$ \\
\hline AR & C12ORF65 & See table $1 \mathrm{~b}$ \\
AR & TFG & See table $1 \mathrm{~b}$ \\
\hline AR & ARSA & See table $1 \mathrm{c}$ \\
\hline AR & GALC & See table $1 \mathrm{c}$ \\
AR & MFF & Leigh-like syndrome, see table 1c \\
AR & ERCC6/ERCC8 & See table 1c \\
AR & HEXA & See table 1c \\
\hline
\end{tabular}

$\begin{array}{lll}\text { AR } & \text { HEXB } & \text { See table 1c } \\ \text { AD } & \text { ATAD3A } & \text { See table 1c }\end{array}$

AR MMACHC

$\begin{array}{ll}\text { Mitochondrial } & \\ \text { AR } & \text { FLVCR1 } \\ \text { Mitochondrial } & \text { MTATP6 } \\ \text { AR } & \text { PHYH } \\ \text { AR } & \text { ABHD12 }\end{array}$

Optic neuropathy, PEO, deafness, myelopathy, sensory-motor axonal neuropathy

Infantile optic atrophy, additionally, extra pyramidal disorder (chorea), ataxia, cognitive defects, axonal sensory neuropathy, autonomic neuropathy, pseudo-obstruction Optic atrophy, rarely neuropathy, spasticity, ataxia and extrapyramidal signs

Optic atrophy and progressive visual loss in the first decade, then spasticity, cerebellar ataxia, sensory-motor axonal neuropathy

Hearing loss, optic atrophy, sensory-motor axonal neuropathy Facial and bulbar weakness, sensory ataxia, sensory-motor axonal neuropathy, optic atrophy, sensory neuronal hearing loss

See table $1 b$

stablo

Onset infancy to adulthood; thrombotic thrombocytopenia with encephalopathy, myelopathy, renal and pulmonary complications (can be life threatening), retinitis pigmentosa, axonal motor neuropathy; treat with high-dose B12

Ophthalmoplegia, retinitis pigmentosa, heart block, ptosis

Retinitis pigmentosa, sensory ganglionopathy and abnormal posterior columns on MRI

See table $1 a$

See table $1 \mathrm{a}$

See table $1 \mathrm{a}$ 
Neuromuscular

\begin{tabular}{|c|c|c|c|}
\hline Disease (OMIM) & Inheritance & Gene & Clinical description \\
\hline AMACRD (614307) & AR & $A M A C R$ & See table $1 \mathrm{~b}$ \\
\hline Cockayne syndrome (216400/133540) & AR & ERCC6/ERCC8 & See table $1 \mathrm{c}$ \\
\hline PBD9B (Refsum variant) (614879) & AR & PEX7 & See table $1 \mathrm{c}$ \\
\hline $\begin{array}{l}\text { Congenital disorder of glycosylation type } 1 \mathrm{~A} \\
(212065)\end{array}$ & AR & PMM2 & See table $1 \mathrm{c}$ \\
\hline $\begin{array}{l}\text { Congenital cataracts, facial dysmorphism and } \\
\text { neuropathy (604168) }\end{array}$ & AR & CTDP1 & $\begin{array}{l}\text { Rudari Gypsies, congenital cataracts and microcornea, facial } \\
\text { dysmorphism, mild cognitive impairment, neuropathy with } \\
\text { SNCV }\end{array}$ \\
\hline CMTD1B or CMT2M (606482) & AR & DNM2 & $\begin{array}{l}\text { Intermediate CMT or CMT2, cataracts, ophthalmoplegia, } \\
\text { ptosis }\end{array}$ \\
\hline Cerebrotendinous xanthomatosis (213700) & AR & CRP27A1 & See table 1a \\
\hline \multicolumn{4}{|c|}{ (c) Cranial and peripheral neuropathy syndromes } \\
\hline FAP-4 (105120) & $A D$ & GSN & Corneal lattice dystrophy, cranial neuropathies, cutix laxa \\
\hline Kearns-Sayre syndrome (530000) & mDNA deletions & & Ophthalmoplegia, retinitis pigmentosa, heart block, ptosis \\
\hline $\begin{array}{l}\text { MTDPS8B } \\
(612075)\end{array}$ & AR & $R R M 2 B$ & PEO, MNGIE, minimal neuropathy \\
\hline $\begin{array}{l}\text { CFEOMA3 } \\
\text { (600638) }\end{array}$ & $A D$ & TUBB3 & $\begin{array}{l}\text { Congenital strabismus, rarely isolated axonal sensory-motor } \\
\text { neuropathy, dysgenesis of the corpus callosum, finger and } \\
\text { wrist contractures, developmental delay, Kallmann syndrome }\end{array}$ \\
\hline SBMA (313200) & $\mathrm{XL}$ & $A R$ & $\begin{array}{l}\text { Motor neuropathy, facial fasciculations, tremor, androgen } \\
\text { insensitivity }\end{array}$ \\
\hline $\begin{array}{l}\text { BVVLS2 } \\
(614707)\end{array}$ & AR & SLC52A2 & $\begin{array}{l}\text { Facial and bulbar weakness, sensory ataxia, sensory-motor } \\
\text { axonal neuropathy, optic atrophy, sensory neuronal hearing } \\
\text { loss }\end{array}$ \\
\hline MELAS (540000) & mitochondrial & MTTL1 m3243A>G & $\begin{array}{l}\text { Myopathy, deafness, ophthalmoplegia, diabetes, stroke like } \\
\text { episodes, predominantly sensory axonal neuropathy }\end{array}$ \\
\hline NF2 (101000) & $A D$ & NF2 & $\begin{array}{l}\text { Bilateral acoustic schwannomas. Axonal sensory-motor } \\
\text { neuropathy }\end{array}$ \\
\hline $\begin{array}{l}\text { Kanzaki disease } \\
(609242)\end{array}$ & AR & NAGA & $\begin{array}{l}\text { Adult-onset-diffuse angiokeratoma, sensory-neural hearing } \\
\text { loss, recurrent episodes of vertigo, sensory-motor axonal } \\
\text { neuropathy. Periventricular white matter abnormalities on } \\
\text { MRI }\end{array}$ \\
\hline HSN1E (614116) & $A D$ & DNMT1 & Dementia, deafness and sensory neuropathy \\
\hline ACPHD (616192) & AR & DNAJC3 & Deafness. See table 1a \\
\hline PHARC syndrome (612674) & AR & ABHD12 & Deafness. See table 1a \\
\hline Refsum's disease (266500) & AR & PHYH & Deafness. See table 1a \\
\hline PBD9B (Refsum variant) (614879) & AR & PEX7 & Deafness. See table $1 \mathrm{c}$ \\
\hline MEDNIK (609313) & AR & AP1S1 & Deafness. See table 1c \\
\hline MTDPS5 (612073) & AR & SUCLA2 & Deafness. See table $1 \mathrm{c}$ \\
\hline MTDPS4B (613662) & AR & POLG & Deafness. See table 2a \\
\hline CMTX5 (311070) & X-linked & PRPS1 & Deafness. See table $2 b$ \\
\hline \multicolumn{4}{|c|}{ (d) Endocrinopathy and neuropathy syndromes } \\
\hline $\begin{array}{l}\text { Gonadal dysgenesis with minifascicular } \\
\text { neuropathy } \\
(607080)\end{array}$ & $A R$ & $\mathrm{DHH}$ & Gonadal dysgenesis, sensory-motor axonal neuropathy \\
\hline Adrenoleukodystrophy (300100) & $\mathrm{XL}$ & $A B C D 1$ & Adrenal failure. See table $1 \mathrm{~b}$ \\
\hline AAAS (231550) & AR & AAAS & Adrenal failure. See table $1 \mathrm{c}$ \\
\hline
\end{tabular}


Table 2 Continued

\begin{tabular}{|c|c|c|c|}
\hline Disease (OMIM) & Inheritance & Gene & Clinical description \\
\hline SBMA (313200) & X-linked & $A R$ & Androgen insensitivity. See table $2 c$ \\
\hline \multicolumn{4}{|c|}{ (e) Musculoskeletal/myopathy and neuropathy syndromes } \\
\hline $\begin{array}{l}\text { Merosin-deficient congenital muscular } \\
\text { dystrophy (MDC1A) } \\
(607855)\end{array}$ & AR & LAMA2 & $\begin{array}{l}\text { Congenital muscular dystrophy, mildly slowed PNS } \\
\text { conduction, abnormal T2 MRI signal white matter }\end{array}$ \\
\hline MFM6 (612954) & AR & $B A G 3$ & $\begin{array}{l}\text { Giant axons on nerve biopsy, myofibrillar myopathy, } \\
\text { cardiomyopathy, scoliosis, sensory-motor axonal neuropathy }\end{array}$ \\
\hline $\begin{array}{l}\text { Limb girdle muscular dystrophy and neuropathy } \\
(181350)\end{array}$ & $A D$ & LMNA & $\begin{array}{l}\text { Limb girdle muscular dystrophy, cardiomyopathy, sensory- } \\
\text { motor axonal neuropathy }\end{array}$ \\
\hline MERRF $(545000)$ & $m 8313 G>A$ m8344A $>G$ & MTTK & $\begin{array}{l}\text { Myoclonic epilepsy, myopathy, lipoma, sensory axonal } \\
\text { neuropathy }\end{array}$ \\
\hline $\begin{array}{l}\text { Multiple acyl-CoA dehydrogenase deficiency } \\
(231680)\end{array}$ & AR & ETFDH & $\begin{array}{l}\text { Neonatal and late onset forms. hypoglycaemia, metabolic } \\
\text { acidosis, and hepatomegaly often preceded by metabolic } \\
\text { stress. Muscle involvement in the form of pain, weakness, } \\
\text { and lipid storage myopathy also occur. Riboflavin responsive }\end{array}$ \\
\hline HMN2A (158590) & $A D$ & HSPB8 & Distal hereditary motor neuropathy and proximal myopathy \\
\hline HMN2B (608634) & $A D$ & HSPB1 & $\begin{array}{l}\text { Distal hereditary motor neuropathy. Myopathic changes on } \\
\text { muscle biopsy }\end{array}$ \\
\hline $\begin{array}{l}\text { Lethal congenital contracture syndrome } 7 \\
(602346)\end{array}$ & AR & CNTNAP1 & $\begin{array}{l}\text { Congenital severe arthrogryposis multiplex congenital, } \\
\text { demyelinating neuropathy }\end{array}$ \\
\hline PNMHH (614369) & AR & MYH14 & See table $2 c$ \\
\hline \multicolumn{4}{|l|}{ (f) Cardiomyopathy and neuropathy syndromes } \\
\hline FAP-1 (105210) & $A D$ & TTR & $\begin{array}{l}\text { Dysautonomia, cardiac disease carpel tunnel syndrome, } \\
\text { painful sensory-motor axonal neuropathy, SNCV may mimic } \\
\text { CIDP }\end{array}$ \\
\hline $\begin{array}{l}\text { Fabry disease } \\
(301500)\end{array}$ & X-linked & $G L A$ & $\begin{array}{l}\text { Angiokeratoma, painful sensory axonal and small fibre } \\
\text { neuropathy, cardiomyopathy, renal failure }\end{array}$ \\
\hline Mitochondrial complex V deficiency (516070) & $m 8529 G>A$ & MTATP8 & $\begin{array}{l}\text { Hypertrophic cardiomyopathy, ataxia, PEO, dysarthria, } \\
\text { sensory-motor axonal neuropathy }\end{array}$ \\
\hline NARP $(551500)$ & Mitochondrial & MTATP6 & See table 1a \\
\hline Friedreich's ataxia (229300) & $\mathrm{AR}$ & $F X N$ & See table $1 a$ \\
\hline HAYOS (617183) & $A D$ & ATAD3A & See table $1 c$ \\
\hline McLeod syndrome (300842) & $\mathrm{XL}$ & $X K$ & See table $2 a$ \\
\hline Kearns-Sayre syndrome (530000) & mitochondrial & & See table $2 b$ \\
\hline MFM6 (612954) & AR & $B A G 3$ & See table $2 \mathrm{e}$ \\
\hline
\end{tabular}

(g) Hepatic, gastrointestinal and neuropathy syndromes

Hepatic

MTDPS3 (251880)

MTDPS6 (256810)

SCAR21 (607982)

Tyrosinemia type 1 (276700)

Gastrointestinal

MTDPS1

(603041)

MTDPS4B (613662)

AR

AR

$A R$

AR

AR

$A R$

$A D$

$A D$

AR

AR

DGUOK

MPV17

SCYL1

FAH

TYMP

POLG

MTDPS8B (612075)

Familial visceral amyloidosis (105200)

Somatic and autonomic neuropathy

Goldberg-Shprintzen megacolon syndrome

with associated sensory motor axonal

neuropathy (609460)
Neonatal liver failure, myopathy, sensory-motor axonal neuropathy

Corneal opacification, neonatal liver failure, acromutilation, sensory axonal neuropathy

See table $1 \mathrm{a}$

See table $2 h$

MNGIE: chronic pseudo-obstruction, sensory-motor neuropathy with slow conduction (may mimic CIDP), myopathic weakness, cachexia. Leukodystrophy on MRI MNGIE: chronic pseudo-obstruction, axonal sensory ataxic neuropathy, myopathic weakness, cachexia. Normal brain MRI

PEO, MNGIE, minimal neuropathy

Adult-onset chronic diarrhoea. Autonomic and sensory-motor axonal neuropathy

Autonomic and sensory axonal neuropathy preceding cognitive decline, chronic diarrhoea

Intellectual disability, microcephaly, dysmorphic facies, Hirschsprung disease, pachygyria, cerebellar hypoplasia (defect in neural crest migration) 


\begin{tabular}{|c|c|c|c|}
\hline Disease (OMIM) & Inheritance & Gene & Clinical description \\
\hline $\begin{array}{l}\text { Waardenburg syndrome type 2E (611584)/ } \\
\text { PWCH (609136) }\end{array}$ & $A D$ & sox10 & $\begin{array}{l}\text { Hypopigmentation of the hair and skin, sensory hearing } \\
\text { loss, demyelinating neuropathy, dysmyelinating } \\
\text { leukodystrophy, developmental delay, spasticity, ataxia, } \\
\text { Hirschsprung disease }\end{array}$ \\
\hline AAAS (231550) & AR & $A A A S$ & Achalasia. See table $1 \mathrm{c}$ \\
\hline FAP-1 (105210) & $A D$ & $T T R$ & See table $2 f$ \\
\hline \multicolumn{4}{|l|}{ (h) Renal failure and neuropathy syndromes } \\
\hline FAP-3 (105200) & $A D$ & APOA1 & $\begin{array}{l}\text { Axonal sensory-motor neuropathy similar to TTR FAP, amyloid } \\
\text { nephropathy }\end{array}$ \\
\hline $\begin{array}{l}\text { Action myoclonus-renal failure syndrome } \\
(254900)\end{array}$ & AR & SCARB2 & $\begin{array}{l}\text { Progressive myoclonic epilepsy with preserved cognition, } \\
\text { onset second decade, renal impairment, rarely demyelinating } \\
\text { sensory-motor neuropathy (without renal failure) }\end{array}$ \\
\hline Fabry disease (301500) & X-Linked & GLA & See table $2 f$ \\
\hline MMACHC (277400) & AR & MMACHC & Thrombotic microangiopathy of kidneys. See table $2 \mathrm{i}$ \\
\hline \multicolumn{4}{|c|}{ (i) Haematological and immunological neuropathy syndromes } \\
\hline MMACHC (277400) & AR & MMACHC & $\begin{array}{l}\text { Onset infancy to adulthood; thrombotic thrombocytopenia } \\
\text { with encephalopathy, myelopathy, renal and pulmonary } \\
\text { complications (can be life threatening), retinitis pigmentosa, } \\
\text { axonal motor neuropathy. Treated with high-dose vitamin } \\
\text { B12 }\end{array}$ \\
\hline Chediak-Higashi syndrome (214500) & AR & LYST & $\begin{array}{l}\text { Partial albinism, immunodeficiency, cerebellar atrophy, } \\
\text { sensory-motor axonal neuropathy }\end{array}$ \\
\hline $\begin{array}{l}\text { Early-onset chronic axonal neuropathy, strokes, } \\
\text { and haemolysis: inherited CD59 deficiency } \\
(612300)\end{array}$ & AR & CD59 & $\begin{array}{l}\text { Onset first and second decade. Haemolytic anaemia, strokes } \\
\text { and relapsing immune-mediated demyelinating neuropathy }\end{array}$ \\
\hline EDS6 (225400) & AR & PLOD1 & $\begin{array}{l}\text { Congenital hypotonia, joint laxity, scleral fragility, } \\
\text { susceptibility to large vessel injury, mild sensory-motor } \\
\text { axonal neuropathy }\end{array}$ \\
\hline $\begin{array}{l}\text { Connective tissue disorder and peripheral } \\
\text { neuropathy }(130660)\end{array}$ & $A D$ & EMILIN1 & $\begin{array}{l}\text { Aortic aneurysm, skin laxity and sensory-motor axonal } \\
\text { neuropathy (single family reported) }\end{array}$ \\
\hline Refsum's disease (266500) & AR & PHYH & Ichthyosis. See table 1a \\
\hline PBD9B (Refsum variant) (614879) & AR & PEX7 & Ichthyosis. See table 1a \\
\hline Cerebrotendinous xanthomatosis (213700) & AR & CRP27A1 & Xanthoma. See table 1a \\
\hline CEDNIK syndrome (609528) & AR & SNAP29 & Icthyosis and palmoplantar keratoderma. See table 1c \\
\hline MEDNIK (609313) & AR & AP1S1 & Icthyosis and palmoplantar keratoderma. See table 1c \\
\hline Cockayne syndrome (216400/133540) & AR & ERCC6/ERCC8 & Cutaneous photosensitivity. See table $1 \mathrm{c}$ \\
\hline FAP-4 (105120) & $A D$ & GSN & Cutis laxa. See table $2 c$ \\
\hline Kanzaki disease (609242) & AR & NAGA & Angiokeratoma. See table $2 c$ \\
\hline Fabry disease $(301500)$ & X-linked & $G L A$ & Angiokeratoma. See table $2 c$ \\
\hline \multicolumn{4}{|c|}{ (k) Relapsing complex inherited neuropathy syndromes } \\
\hline Porphyria, acute intermittent (AIP) (176000) & $A D$ & $H M B S$ & $\begin{array}{l}\text { Abdominal pain, psychosis, depression, seizures, axonal } \\
\text { predominantly motor neuropathy }\end{array}$ \\
\hline Coproporphyria (121300) & $A D$ & CPOX & $\begin{array}{l}\text { Skin photosensitivity and haemolytic anaemia. Can present } \\
\text { acutely similar to AIP }\end{array}$ \\
\hline Porphyria, variegata (176200) & $A D$ & $P P O X$ & Skin photosensitivity. Acute episodes similar to AIP \\
\hline Tyrosinemia type 1 (276700) & AR & FAH & $\begin{array}{l}\text { Infantile or adolescent onset liver disease, renal tubular } \\
\text { dysfunction and hypophosphatemic rickets. Acute episodes } \\
\text { of neuropathy similar to AIP }\end{array}$ \\
\hline
\end{tabular}


Table 2 Continued

\begin{tabular}{|c|c|c|c|}
\hline Disease (OMIM) & Inheritance & Gene & Clinical description \\
\hline $\begin{array}{l}\text { Trifunctional protein deficiency with myopathy } \\
\text { and neuropathy (609015) }\end{array}$ & $A R$ & $\begin{array}{l}\text { HADHA } \\
\text { HADHB }\end{array}$ & $\begin{array}{l}\text { Disorder of mitochondrial beta oxidation of fatty acids. } \\
\text { Severe neonatal, infantile and late adolescent onset } \\
\text { described, the latter characterised by a progressive myopathy } \\
\text { with recurrent rhabdomyolysis and a sensory-motor axonal } \\
\text { neuropathy. Abnormal urine organic acids }\end{array}$ \\
\hline Maple syrup urine disease $\mathrm{lb}(248600)$ & AR & $B C K D H B$ & $\begin{array}{l}\text { Metabolic encephalopathy, elevated branched chain amino } \\
\text { acids in urine, acute axonal neuropathy }\end{array}$ \\
\hline $\begin{array}{l}\text { Thiamine metabolism dysfunction syndrome } 4 \\
\text { THMD4 (613710) }\end{array}$ & AR & $S L C 25 A 19$ & $\begin{array}{l}\text { Acute encephalopathic episodes and paralysis following } \\
\text { febrile illness with almost complete recovery. Absent sensory- } \\
\text { motor action potential during illness. Bilateral striatal } \\
\text { necrosis on MRI. Additional chronic progressive axonal } \\
\text { neuropathy }\end{array}$ \\
\hline Tangier disease (205400) & $A R$ & $A B C 1$ & $\begin{array}{l}\text { Multifocal relapsing mononeuropathies. Orange tonsils, } \\
\text { organomegaly; pain, paraesthesias, anaesthesia }\end{array}$ \\
\hline $\begin{array}{l}\text { Inherited CD59 deficiency } \\
(612300)\end{array}$ & $A R$ & CD59 & See table $2 \mathrm{i}$ \\
\hline
\end{tabular}

Number in parenthesis is the OMIM phenotype number.

$A R$, autosomal recessive; $A D$, autosomal dominant; $B V V L$, Brown-Vialetto-Van Laere syndrome; CFEOMA3, fibrosis of extraocular muscles, congenital, $3 A$, with or without extraocular involvement; CSF, cerebrospinal fluid; EAO, Early age of onset; EDS, Ehlers-Danlos syndrome; FAP, familial amyloid polyneuropathy; FLAIR, Fluid-Attenuated Inversion Recovery; HMN, hereditary motor neuropathy; HNRAMD, neuropathy, hereditary, with or without age-related macular degeneration; MELAS, mitochondrial myopathy, encephalopathy; MERFF, myoclonic epilepsy associated with ragged red fibres; MFM, myofibrillar myopathy; MNGIE, mitochondrial neuro gastrointestinal encephalopathy; MTDPS, mitochondrial DNA depletion syndrome; NARP, neuropathy, ataxia, retinitis pigmentosa; NF2, neurofibromatosis type 2; OMIM, Online Mendelian Inheritance in Man; PEO, progressive external ophthalmoplegia; PNMHH, peripheral neuropathy, myopathy, hoarseness and hearing loss, lactic acidosis and stroke-like episodes; PWCH, peripheral demyelinating neuropathy, central demyelination, Waardenburg syndrome; SBMA, spinal bulbar muscular atrophy; SNCV, slow nerve conduction velocities.

mutations in either OPA1 or OPA3. ${ }^{\text {w67 w68 }}$ These patients often have other clinical features including pseudo-obstruction, deafness, extrapyramidal signs and progressive external ophthalmoplegia. Mutations in MFN2, the cause of CMT2A, may also cause optic atrophy and an axonal neuropathy but in almost all cases the neuropathy predominates. ${ }^{\text {w69 }}$

Retinitis pigmentosa is a relatively common feature among the complex neuropathy syndromes, particularly disorders of mitochondria (eg, Kearns-Sayre and NARP syndromes) and the peroxisome (Refsum's and related diseases including AMACRD). ${ }^{734 \mathrm{w} 70}$ In addition, retinitis pigmentosa is also a feature of several other rare conditions including PHARC syndrome and the congenital disorders of glycosylation. ${ }^{2151}$ Most importantly, it is a feature of a treatable (high doses of B12) genetic B12 deficiency syndrome (MMACHC), in which vitamin B12 plasma levels are normal but the downstream metabolites methylmalonic acid and homocysteine are elevated. ${ }^{\text {w71 }}$

Cataracts are common in the general population but are helpful diagnostically if present in young patients. Although present in several conditions, for example, PHARC, congenital cataracts facial dysmorphism and neuropathy (CCFDN) and HLD5, ${ }^{2150}$ w72 most importantly they are a feature of the treatable disease cerebrotendinous xanthomatosis and their presence should prompt testing of plasma cholastenol levels. ${ }^{11}$

\section{Cranial neuropathies and deafness (table 2c)}

Bilateral facial weakness and bulbar palsy is an uncommon phenotype in the complex neuropathy syndromes and strongly suggestive of spinal bulbar muscular atrophy (Kennedy's disease) or Brown-Vialetto-Van Laere (BVVL) syndromes. ${ }^{\text {w73 }}{ }^{774}$ Of these, BVVL is an important diagnosis not to miss. It is due to recessive mutations in one of two riboflavin transporters and both forms appear to respond to riboflavin supplementation. ${ }^{\mathrm{w} 74 \mathrm{w} 75}$ BVVL is almost always associated with deafness. In BVVLS2, patients often present with a sensory ataxic neuropathy whereas in BVVLS1 it is predominantly a motor neuronopathy. Some but not all patients with BVVLS2 may have an abnormal plasma acyl carnitine profile. ${ }^{\text {w74 }}$
Progressive external ophthalmoplegia is the the most common disorder of cranial musculature and is seen with both nuclear and mitochondrial DNA mutations. ${ }^{\text {w76 }}$ The presence of Duane syndrome, a congenital and non-progressive strabismus with a mild sensory and motor axonal neuropathy is seen with dominant mutations in TUBB3. ${ }^{\mathrm{w} 77}$

Sensory neuronal deafness as part of a complex neuropathy syndrome is commonly, but not exclusively, seen with mitochondrial disorders. The presence of sensory neuronal hearing loss in combination with a myopathy, although most commonly seen with mitochondrial disease, is also a feature of a distal myopathy and neuropathy overlap syndrome caused by mutations in MYH14. ${ }^{\text {w78 }}$ The combination of ataxia, demyelinating neuropathy and sensory neuronal hearing loss is common to both PHARC syndrome and ACPHD. ${ }^{20} 21$ Finally, although classified as an HSN, HSN1E is defined by the presence of sensory neuronal hearing loss in combination with dementia and, in some cases, narcolepsy. ${ }^{\mathrm{w} 79}$

\section{Endocrinopathy and neuropathy syndromes (table 2d)}

Although diabetes mellitus is a feature of mitochondrial disease and a number of other complex syndromes including APCHD and Kennedy's disease, its high prevalence in the general population reduces its discriminatory value. ${ }^{20 \mathrm{w} 73}$ Adrenal insufficiency, however, is a useful diagnostic clue for adrenomyeloneuropathy but also the achalasia, hypo adrenalism, alacrima syndrome (AAAS). ${ }^{\text {w80 }}$ Ambiguous genitalia in combination with global neurodevelopmental impairment and a mixed sensory and motor axonal neuropathy is seen in the gonadal dysgenesis with minifascicular neuropathy syndrome. ${ }^{\text {w81 }}$

Musculoskeletal/myopathy and neuropathy syndromes (table 2e) The presence of a myopathy in combination with a leukodystrophy, ataxia, global developmental delay and a sensory and motor peripheral neuropathy with SNCV is almost diagnostic of congenital disorder of glycosylation type $1 \mathrm{~A} .{ }^{51} \mathrm{~A}$ mild neuropathy 
with slow conduction velocities is also seen in merosin-deficient congenital muscular dystrophy but is not a dominant feature. ${ }^{\mathrm{w} 82}$ To date, a sensory and motor axonal peripheral neuropathy with giant axons has been described in myofibrillar myopathy due to recessive mutations in $B A G 3$, but the clinical phenotype is dominated by the myopathy and cardiomyopathy. ${ }^{\mathrm{w} 83}$ Recessive mutations in lamin A/C are a cause of CMT2 in North Africa; however, dominant mutations in the same gene causing a limb girdle muscular dystrophy may rarely be associated with a sensory and motor axonal neuropathy. ${ }^{\mathrm{w} 4}$

To date, only a subclinical sensory axonal neuropathy has been described in patients with multiple acyl CoA dehydrogenase deficiency. It is possible that forms of the disease exist in which neuropathy is a more prominent feature. The disease is characterised by episodes of hypoglycaemia, acidosis and a lipid storage myopathy. Most importantly, it is responsive to riboflavin supplementation. ${ }^{\text {w85 }}$

Finally, genes that were originally reported to cause distal HMN are now recognised to cause both a myopathy and motor neuropathy. ${ }^{\mathrm{w} 86 \mathrm{w} 87}$ This is most pronounced for patients with mutations in HSPB8 in whom the myofibrillar myopathy dominates the clinical picture. ${ }^{87}$

\section{Cardiomyopathy and neuropathy syndromes (table 2f)}

Cardiomyopathy is seen in a number of complex inherited neuropathy syndromes including myofibrillar myopathy due to $B A G 3$ mutations, mitochondrial disease, Fabry disease, Friedreich's ataxia and McLeod's syndrome.

The presence of an acquired cardiomyopathy in adulthood in combination with a painful sensory and motor axonal neuropathy is highly suggestive of familial amyloid polyneuropathy. Although tissue confirmation of amyloid is important, in the correct clinical context, sequencing of the TTR gene is warranted as a number of old (liver transplantation) and new (tafamidis and diflunisal) treatments are available. ${ }^{\text {w88 }}$ A significant minority of patients with TTR amyloidosis have been reported with an SNCV neuropathy mimicking CIDP (eg, see supplementary file 1).

\section{Hepatic, GI and neuropathy syndromes (table $2 \mathrm{~g}$ )}

Recurrent episodes of acute liver failure in combination with a neuropathy is suggestive of mitochondrial disease and has been described with mutations in the nuclear genes DGUOK and MPV17 and can occur in autosomal-recessive spinocerebellar ataxia $21 .^{\mathrm{w} 89 \mathrm{w} 90}$

Hirschsprung disease is a developmental disorder of the mesenteric plexus and, in combination with global developmental delay and a neuropathy with SNCV, is seen with dominant mutations in SOX10. ${ }^{\text {w91 }}$ The association of Hirschsprung disease, global neurodevelopmental impairment and an axonal sensory and motor neuropathy is seen in Goldberg-Shprintzen megacolon syndrome due to recessive mutations in KIAA1279. ${ }^{\text {} 92}$

Pseudo obstruction is an increasingly recognised complication of mitochondrial disease and can be caused by a number of gene mutations including $P O L G, R R M 2 B$ and TPP. ${ }^{\text {w89 }}$ In its most severe form, mitochondrial neurogastrointestinal encephalopathy (MNGIE) patients may present with a neuropathy resembling CMT or chronic inflammatory demyelinating polyneuropathy associated with severe GI disturbance and weight loss. ${ }^{\text {w93 }}$ It is most commonly due to recessive mutations in the nuclear gene thymidine phosphorylase and can be screened for by testing for elevated levels of thymidine and deoxyuridine in plasma. The disease arises from a deficiency of the enzyme thymidine phosphorylase, which is expressed in platelets. Allogenic bone marrow and liver transplantation have been successfully employed as treatments for this condition. ${ }^{\mathrm{w} 89} \mathrm{w}$ w9

The combination of adult-onset refractory diarrhoea, sensory axonal neuropathy and dysautonomia is suggestive of familial amyloid polyneuropathy but also rarely mutations in the prion protein gene, $P R N P .{ }^{\mathrm{w} 95}$ In the latter it is associated with dementia but this often occurs late in the disease.

\section{Renal failure and neuropathy syndromes (table $2 \mathrm{~h}$ )}

Renal failure is rare in the complex inherited neuropathy syndromes. Nephropathy is a feature of familial amyloid polyneuropathy but it is rare for patients with mutations in TTR to develop frank renal failure. Renal failure is also seen in Fabry disease, an X-linked disorder associated with a painful sensory and small fibre neuropathy, angiokeratoma, strokes and a cardiomyopathy.

An intermediate form of CMT due to dominant mutations in INF2, a gene expressed in the glomerulus and peripheral nerve, is associated with a focal segmental glomerulosclerosis. ${ }^{\text {w96 }}$ In almost all cases, the degree of renal failure eventually requires renal replacement therapy. The recently described action myoclonus-renal failure syndrome is characterised by a progressive myoclonic epilepsy and renal failure beginning in the second decade of life and associated with a sensory and motor neuropathy with slow conduction velocities. ${ }^{9}{ }^{97}$

Haematological and immunological neuropathy syndromes (table 2i) The combination of haematological abnormalities and a peripheral neuropathy is unique to a small number of syndromes. The most important to recognise are the disorders of cobalamin (B12) metabolism that result in functional B12 deficiency. The most common of this group of diseases is methylmalonic aciduria and homocystinuria, cb1C (MMACHC), which can cause a syndrome similar to subacute combined degeneration of the cord but also other haematological abnormalities including a form of vitamin B12-responsive thrombotic thrombocytopenic purpura. ${ }^{\mathrm{w} 71}$

Autosomal-recessive mutations in CD59, a glycoprotein present on the cell surface that prevents formation of the complement-mediated membrane attack complex, results in a combination of haemolytic anaemia, strokes and a relapsing remitting demyelinating neuropathy. Eculizumab, an inhibitor of the complement membrane attack complex, has been used successfully in one patient. ${ }^{\text {w98 }}$

Chediak-Higashi syndrome is an immunodeficiency syndrome characterised by neutropenia and an increased risk of lymphoma. It is associated with a sensory and motor axonal peripheral neuropathy and has been treated with allogenic bone marrow transplantation in selected cases. ${ }^{\text {} 99}$

\section{Skin and connective tissue and neuropathy syndromes (table 2j)}

Photosensitivity is a rare symptom but in combination with a peripheral sensory and motor axonal neuropathy is suggestive of xeroderma pigmentosa (XP), a disease which is associated with developmental delay and an increased risk of cutaneous malignancy. ${ }^{\text {w100 }}$ Patients with Cockayne syndrome also experience skin photosensitivity, but unlike XP, the neuropathy has SNCV and there is no increased risk of malignancy. ${ }^{53}$

Skin laxity is an uncommon sign but is seen in combination with a SNCV neuropathy in dominant FBLN5 mutations, and in combination with a mixed sensory and motor axonal neuropathy with recessive mutations of PLOD1 and dominant mutations in 
EMILIN1. ${ }^{\text {w101 w102 }}$ It is important to recognise these two diseases as patients have an increased risk of large vessel injury and aneurysms and may need to enter an aneurysm screening programme. (c) Article author(s) (or their employer(s) unless otherwise stated in the text of the article) 2017. All rights reserved. No commercial use is permitted unless otherwise expressly granted.

\section{Relapsing complex inherited neuropathy syndromes (table 2k)}

This group of diseases are important to recognise as they are more likely to have an underlying metabolic defect and are often treatable. The acute porphyrias, including acute intermittent porphyria, coproporphyria and variegate porphyria, can present as an acute neuropathy mimicking Guillain-Barré syndrome. ${ }^{\text {w103 }}$ In AIP, relapses are associated with abdominal pain and seizures whereas in variegate and coproporphyria there is skin photosensitivity. These diseases can be screened for acutely by testing for porphobilinogen in a light-protected sample of urine. Identification of acute porphyria is important as early treatment with glucose and haematin in patients with an acute axonal neuropathy may improve the prognosis.

Tyrosinemia can present similarly to acute intermittent porphyria. It is diagnosed by the detection of raised levels of succinylacetone in blood and urine. In the acute setting, it is treated with plasma exchange. Nitisinone, which prevents the formation of the toxic products malcylacetoacetic acid and fumarylacetoacetic acid, offers a long-term treatment. ${ }^{\text {w104 }}$

Maple syrup urine disease has been reported as a cause of an acute axonal neuropathy mimicking Guillain-Barré syndrome and is treated with dietary reduction of protein intake. ${ }^{\text {w105 }}$ Thiamine metabolism dysfunction syndrome 4 is a condition characterised by a progressive chronic axonal neuropathy superimposed by episodes of acute encephalopathy and paralysis following a febrile illness. Thiamine is an unproven but recognised treatment. ${ }^{\text {w106 }}$

\section{CONCLUSION}

Although the advent of NGS means that it is now feasible to sequence all known complex inherited neuropathy genes in a practical time frame, an overview of the phenotypes is still required to be able to help decide which novel variants are benign, which are pathogenic and which disease genes may not have been comprehensively screened using current NGS platforms. Obtaining an accurate genetic diagnosis in these conditions can be of great benefit to patients and their families especially for genetic counselling and to prevent unnecessary investigations. In this rapidly growing field, the identification of those diseases that may respond to treatment will always be the top priority, particularly as the number of treatable conditions increases.

\section{Acknowledgements MMR, SSS, MES and DP are grateful to the National Institutes of Neurological Diseases and Stroke and office of Rare Diseases (U54NS065712) for their support.}

Contributors AMR performed a literature search, analysed the literature, wrote the first draft including tables and figures. ASC, ALP-N and HD performed additional literature searches and drafted manuscripts. HC collected MRI images and drafted the legend for figure 2. DP, SSS and MES revised the manuscript. SSS performed an additional literature search to identify additional diseases. MMR came up with the theme for the review and revised the manuscruipt.

Funding The INC (U54NS065712) is a part of the NCATS Rare Diseases Clinical Research Network (RDCRN). RDCRN is an initiative of the Office of Rare Diseases Research (ORDR), NCATS, funded through a collaboration between NCATS and the NINDS. This research was also supported by the National Institute for Health Research University College London Hospitals Biomedical Research Centre. AMR is funded by a Wellcome Trust Postdoctoral Fellowship for Clinicians (110043/Z/15/Z). MMR is grateful to the Medical Research Council (MRC), MRC Centre grant (G0601943).

Competing interests None declared.

Provenance and peer review Commissioned; externally peer reviewed.

\section{REFERENCES}

1 Rossor AM, Tomaselli PJ, Reilly MM. Recent advances in the genetic neuropathies. Curr Opin Neurol 2016:29:1.

2 Ivanova N, Claeys KG, Deconinck T, et al. Hereditary spastic paraplegia 3A associated with axonal neuropathy. Arch Neurol 2007:64:706.

3 Guelly C, Zhu PP, Leonardis L, et al. Targeted high-throughput sequencing identifies mutations in atlastin-1 as a cause of hereditary sensory neuropathy type I. Am J Hum Genet 2011:88:99-105.

4 Adachi $\mathrm{H}$, Ishihara $\mathrm{K}$, Tachibana $\mathrm{H}$, et al. Adult-onset Krabbe disease presenting with an isolated form of peripheral neuropathy. Muscle Nerve 2016:54:152-7.

5 Cottenie E, Kochanski A, Jordanova A, et al. Truncating and missense mutations in IGHMBP2 cause Charcot-Marie Tooth disease type 2. Am J Hum Genet 2014;95:590-601.

6 Rossor AM, Polke JM, Houlden $\mathrm{H}$, et al. Clinical implications of genetic advances in Charcot-Marie-Tooth disease. Nat Rev Neurol 2013;9:562-71.

7 Wanders RJ, Waterham HR, Leroy BP. Disease Refsum. 1993.

8 Shapiro E, Krivit W, Lockman L, et al. Long-term effect of bone-marrow transplantation for childhood-onset cerebral X-linked adrenoleukodystrophy. Lancet 2000:356:713-8

9 Sessa M, Lorioli L, Fumagalli F, et al. Lentiviral haemopoietic stem-cell gene therapy in early-onset metachromatic leukodystrophy: an ad-hoc analysis of a nonrandomised, open-label, phase 1/2 trial. Lancet 2016;388:476-87.

10 Devalia V, Hamilton MS, Molloy AM, et al. Guidelines for the diagnosis and treatment of cobalamin and folate disorders. Br J Haematol 2014;166:496-513.

11 Keren Z, Falik-Zaccai TC. Cerebrotendinous xanthomatosis (CTX): a treatable lipid storage disease. Pediatr Endocrinol Rev 2009;7:6-11.

12 Kobayashi H, Abe K, Matsuura T, et al. Expansion of intronic GGCCTG hexanucleotide repeat in NOP56 causes SCA36, a type of spinocerebellar ataxia accompanied by motor neuron involvement. Am J Hum Genet 2011:89:121-30.

13 Gispert S, Kurz A, Waibel S, et al. The modulation of Amyotrophic Lateral Sclerosis risk by ataxin-2 intermediate polyglutamine expansions is a specific effect. Neurobiol Dis 2012;45:356-61.

14 Schöls L, Amoiridis G, Büttner T, et al. Autosomal dominant cerebellar ataxia: phenotypic differences in genetically defined subtypes? Ann Neurol 1997:42:924-32.

15 Storey E. Genetic cerebellar ataxias. Semin Neurol 2014;34:280-92.

16 Riess 0 , Rüb U, Pastore A, et al. SCA3: neurological features, pathogenesis and animal models. Cerebellum 2008;7:125-37.

17 Rüb U, Schöls L, Paulson H, et al. Clinical features, neurogenetics and neuropathology of the polyglutamine spinocerebellar ataxias type 1, 2, 3, 6 and 7 . Prog Neurobiol 2013;104:38-66.

18 O'Hearn E, Holmes SE, Margolis RL. Spinocerebellar ataxia type 12. Handb Clin Neurol 2012;103:535-47.

19 Synofzik M, Soehn AS, Gburek-Augustat J, et al. Autosomal recessive spastic ataxia of Charlevoix Saguenay (ARSACS): expanding the genetic, clinical and imaging spectrum. Orphanet J Rare Dis 2013;8:41

20 Synofzik M, Haack TB, Kopajtich R, et al. Absence of BiP co-chaperone DNAJC3 causes diabetes mellitus and multisystemic neurodegeneration. Am J Hum Genet 2014:95:689-97.

21 Fiskerstrand T, H'mida-Ben Brahim D, Johansson S, et al. Mutations in ABHD12 cause the neurodegenerative disease PHARC: an inborn error of endocannabinoid metabolism. Am J Hum Genet 2010;87:410-7.

22 van der Knaap MS, Salomons GS. Leukoencephalopathy with brain stem and spinal cord involvement and lactate elevation. University of Washington, Seattle 1993

23 Brunberg JA, Jacquemont S, Hagerman RJ, et al. Fragile X premutation carriers: characteristic MR imaging findings of adult male patients with progressive cerebellar and cognitive dysfunction. AJNR Am J Neuroradiol 2002;23:1757-66.

24 De Stefano N, Dotti MT, Mortilla M, et al. Magnetic resonance imaging and spectroscopic changes in brains of patients with cerebrotendinous xanthomatosis. Brain 2001;124:121-31.

25 Manzini MC, Rajab A, Maynard TM, et al. Developmental and degenerative features in a complicated spastic paraplegia. Ann Neurol 2010;67:516-25.

26 Coutelier M, Goizet C, Durr A, et al. Alteration of ornithine metabolism leads to dominant and recessive hereditary spastic paraplegia. Brain 2015:138:2191-205.

27 Windpassinger C, Auer-Grumbach M, Irobi J, et al. Heterozygous missense mutations in BSCL2 are associated with distal hereditary motor neuropathy and silver syndrome. Nat Genet 2004;36:271-6

28 Horga A, Tomaselli PJ, Gonzalez MA, et al. SIGMAR1 mutation associated with autosomal recessive Silver-like syndrome. Neurology 2016;87:1607-12.

29 Rainier S, Bui M, Mark E, et al. Neuropathy target esterase gene mutations cause motor neuron disease. Am J Hum Genet 2008;82:780-5. 
30 Liu YT, Laurá M, Hersheson J, et al. Extended phenotypic spectrum of KIF5A mutations: from spastic paraplegia to axonal neuropathy. Neurology 2014;83:612-9.

31 Bouhouche A, Benomar A, Bouslam N, et al. Mutation in the epsilon subunit of the cytosolic chaperonin-containing t-complex peptide-1 (Cct5) gene causes autosomal recessive mutilating sensory neuropathy with spastic paraplegia. J Med Genet 2006;43:441-3.

32 Novarino G, Fenstermaker AG, Zaki MS, et al. Exome sequencing links corticospinal motor neuron disease to common neurodegenerative disorders. Science 2014;343:506-11.

33 Baets J, Deconinck T, Smets K, et al. Mutations in SACS cause atypical and late-onset forms of ARSACS. Neurology 2010;75:1181-8.

34 Ferdinandusse S, Denis S, Clayton PT, et al. Mutations in the gene encoding peroxisomal alpha-methylacyl-CoA racemase cause adult-onset sensory motor neuropathy. Nat Genet 2000;24:188-91.

35 Mochel F, Schiffmann R, Steenweg ME, et al. Adult polyglucosan body disease: natural history and key magnetic resonance Imaging findings. Ann Neurol 2012;72:433-41.

36 Goizet C, Boukhris A, Durr A, et al. CYP7B1 mutations in pure and complex forms of hereditary spastic paraplegia type 5. Brain 2009;132:1589-600.

37 Hofereiter J, Smith MD, Seth J, et al. Bladder and bowel dysfunction is common in both men and women with mutation of the ABCD1 gene for X-Linked adrenoleukodystrophy. JIMD Rep 2015;22:77.

38 Bernardi B, Pini A, Santucci M, et al. MRI findings in patients with clinical onset consistent with infantile neuroaxonal dystrophy (INAD), Literature Review, clinical and MRI Follow-up. Neuroradiol J 2011;24:202-14.

39 Deschauer M, Gaul C, Behrmann C, et al. C19orf12 mutations in neurodegeneration with brain iron accumulation mimicking juvenile amyotrophic lateral sclerosis. J Neurol 2012;259:2434-9.

40 Montecchiani C, Pedace L, Lo Giudice T, et al. ALS5/SPG11/KIAA1840 mutations cause autosomal recessive axonal Charcot-Marie-Tooth disease. Brain 2016:139:73-85.

41 Schüle R, Schlipf N, Synofzik M, et al. Frequency and phenotype of SPG11 and SPG 15 in complicated hereditary spastic paraplegia. J Neurol Neurosurg Psychiatry 2009;80:1402-4.

42 Martin E, Schüle R, Smets K, et al. Loss of function of glucocerebrosidase GBA2 is responsible for motor neuron defects in hereditary spastic paraplegia. Am J Hum Genet 2013;92:238-44.

43 Ravenscroft G, Di Donato N, Hahn G, et al. Recurrent de novo BICD2 mutation associated with arthrogryposis multiplex congenita and bilateral perisylvian polymicrogyria. Neuromuscul Disord 2016;26:744-8.

44 Scoto M, Rossor AM, Harms MB, et al. Novel mutations expand the clinical spectrum of DYNC1H1-associated spinal muscular atrophy. Neurology 2015;84:668-79.

45 Delnooz CC, Lefeber DJ, Langemeijer SM, et al. New cases of adult-onset sandhoff disease with a cerebellar or lower motor neuron phenotype. J Neurol Neurosurg Psychiatry 2010;81:968-72.

46 Mitsumoto H, Sliman RJ, Schafer IA, et al. Motor neuron disease and adult hexosaminidase A deficiency in two families: evidence for multisystem degeneration. Ann Neurol 1985; 17:378-85.

47 Nahorski MS, Al-Gazali L, Hertecant J, et al. A novel disorder reveals clathrin heavy chain-22 is essential for human pain and touch development. Brain 2015;138:2147-60.

48 Cox JJ, Reimann F, Nicholas AK, et al. An SCN9A channelopathy causes congenital inability to experience pain. Nature 2006;444:894-8.

49 Oz-Levi D, Ben-Zeev B, Ruzzo EK, et al. Mutation in TECPR2 reveals a role for autophagy in hereditary spastic paraparesis. Am J Hum Genet 2012;91:1065-72.

50 Biancheri R, Zara F, Bruno C, et al. Phenotypic characterization of hypomyelination and congenital cataract. Ann Neurol 2007:62:121-7.

51 Matthijs G, Schollen E, Pardon E, et al. Mutations in PMM2, a phosphomannomutase gene on chromosome 16p13, in carbohydrate-deficient glycoprotein type I syndrome (Jaeken syndrome). Nat Genet 1997;16:88-92.

52 Howard HC, Mount DB, Rochefort D, et al. The K-Cl cotransporter KCC3 is mutant in a severe peripheral neuropathy associated with agenesis of the corpus callosum. Nat Genet 2002;32:384-92

53 Gitiaux C, Blin-Rochemaure N, Hully M, et al. Progressive demyelinating neuropathy correlates with clinical severity in cockayne syndrome. Clin Neurophysiol 2015;126:1435-9.

54 Echaniz-Laguna A, Ghezzi D, Chassagne M, et al. SURF1 deficiency causes demyelinating Charcot-Marie-Tooth disease. Neurology 2013;81:1523-30.

55 Koch J, Feichtinger RG, Freisinger P, et al. Disturbed mitochondrial and peroxisomal dynamics due to loss of MFF causes Leigh-like encephalopathy, optic atrophy and peripheral neuropathy. J Med Genet 2016;53:270-8.

$56 \mathrm{Hu} \mathrm{H}$, Matter ML, Issa-Jahns L, et al. Mutations in PTRH2 cause novel infantile-onset multisystem disease with intellectual disability, microcephaly, progressive ataxia, and muscle weakness. Ann Clin Trans/ Neurol 2014;1:1024-35.

57 Rice G, Patrick T, Parmar R, et al. Clinical and molecular phenotype of AicardiGoutieres syndrome. Am J Hum Genet 2007;81:713-25.
58 Hahn AF, Gordon BA, Hinton GG, et al. A variant form of metachromatic leukodystrophy without arylsulfatase deficiency. Ann Neurol 1982;12:33-6.

59 Bomont $\mathrm{P}$, Cavalier L, Blondeau F, et al. The gene encoding gigaxonin, a new member of the cytoskeletal BTB/kelch repeat family, is mutated in giant axonal neuropathy. Nat Genet 2000;26:370-4.

60 Fuchs-Telem D, Stewart H, Rapaport D, et al. CEDNIK syndrome results from loss-offunction mutations in SNAP29. Br J Dermatol 2011;164:610-6.

w61 Akizu N, Cantagrel V, Schroth J, et al. AMPD2 regulates GTP synthesis and is mutated in a potentially treatable neurodegenerative brainstem disorder. Cell 2013;154:505-17.

w62 Marsh AP, Lukic V, Pope K, et al. Complete callosal agenesis, Pontocerebellar Hypoplasia, and axonal neuropathy due to AMPD2 loss. Neurol Genet 2015;1:e16.

w63 Bandettini di Poggio M, Nesti C, Bruno C, et al. Dopamine-agonist Responsive Parkinsonism in a patient with the SANDO syndrome caused by POLG mutation. BMC Med Genet 2013;14:105.

w64 Walker RH. Untangling the Thorns: advances in the Neuroacanthocytosis Syndromes. J Mov Disord 2015:8:41-54.

w65 Aerts MB, Weterman MA, Quadri M, et al. A LRSAM1 mutation links Charcot-MarieTooth type 2 to Parkinson's disease. Ann Clin Trans/ Neurol 2016;3:146-9.

w66 Frasquet M, Chumillas MJ, Vílchez JJ, et al. Phenotype and natural history of inherited neuropathies caused by HSJ1 C.352+1G>A mutation. J Neurol Neurosurg Psychiatry 2016:87:1265-8.

w67 Chalmers RM, Bird AC, Harding AE. Autosomal dominant optic atrophy with asymptomatic peripheral neuropathy. J Neurol Neurosurg Psychiatry 1996;60:195-6.

w68 Bonifert T, Karle KN, Tonagel F, et al. Pure and syndromic optic atrophy explained by deep intronic OPA1 mutations and an intralocus modifier. Brain 2014:137:2164-77.

w69 Züchner S, De Jonghe P, Jordanova A, et al. Axonal neuropathy with optic atrophy is caused by mutations in mitofusin 2. Ann Neurol 2006;59:276-81.

w70 Holt IJ, Harding AE, Petty RK, et al. A new mitochondrial disease associated with mitochondrial DNA heteroplasmy. Am J Hum Genet 1990;46:428-33.

w71 Frattini D, Fusco C, Ucchino V, et al. Early onset methylmalonic aciduria and homocystinuria cblC type with demyelinating neuropathy. Pediatr Neurol 2010;43:135-8.

w72 Rossor AM, Tomaselli PJ, Reilly MM. Recent advances in the genetic neuropathies. Curr Opin Neurol 2016;29:537-48.

w73 Kennedy WR, Alter M, Sung JH. Progressive proximal spinal and bulbar muscular atrophy of late onset. A sex-linked recessive trait. Neurology 1968;18:671-80.

w74 Foley AR, Menezes MP, Pandraud A, et al. Treatable childhood neuronopathy caused by mutations in Riboflavin transporter RFVT2. Brain 2014;137:44-56.

w75 Jaeger B, Bosch AM. Clinical presentation and outcome of Riboflavin transporter deficiency: mini review after five years of experience. J Inherit Metab Dis 2016;39:559-64.

w76 Horga A, Pitceathly RD, Blake JC, et al. Peripheral neuropathy predicts nuclear gene defect in patients with mitochondrial ophthalmoplegia. Brain 2014;137:3200-12.

w77 Chew S, Balasubramanian R, Chan WM, et al. A novel syndrome caused by the E410K amino acid substitution in the neuronal $\beta$-tubulin isotype 3. Brain 2013;136:522-35.

w78 Choi BO, Kang SH, Hyun YS, et al. A complex phenotype of peripheral neuropathy, myopathy, hoarseness, and hearing loss is linked to an autosomal dominant mutation in MYH14. Hum Mutat 2011;32:669-77.

w79 Baets J, Duan X, Wu Y, et al. Defects of mutant DNMT1 are linked to a spectrum of neurological disorders. Brain 2015;138:845-61.

w80 Houlden $\mathrm{H}$, Smith S, De Carvalho M, et al. Clinical and genetic characterization of families with triple A (Allgrove) syndrome. Brain 2002;125:2681-90.

w81 Sugie K, Futamura N, Suzumura A, et al. Hereditary motor and sensory neuropathy with minifascicle formation in a patient with 46xy pure gonadal dysgenesis: a new clinical entity. Ann Neurol 2002;51:385-8.

w82 Shorer Z, Philpot J, Muntoni F, et al. Demyelinating peripheral neuropathy in merosindeficient congenital muscular dystrophy. J Child Neurol 1995;10:472-5.

w83 Jaffer F, Murphy SM, Scoto M, et al. BAG3 mutations: another cause of giant axonal neuropathy. J Peripher Nerv Syst 2012;17:210-6

w84 Walter MC, Witt TN, Weigel BS, et al. Deletion of the LMNA initiator codon leading to a neurogenic variant of autosomal dominant Emery-Dreifuss muscular dystrophy. Neuromuscul Disord 2005;15:40-4.

w85 Wang Z, Hong D, Zhang W, et al. Severe sensory neuropathy in patients with adult-onset multiple acyl-CoA dehydrogenase deficiency. Neuromuscul Disord 2016;26:170-5

w86 Lewis-Smith DJ, Duff J, Pyle A, et al. Novel HSPB1 mutation causes both motor neuronopathy and distal myopathy. Neurol Genet 2016;2:e110.

w87 Ghaoui R, Palmio J, Brewer J, et al. Mutations in HSPB8 causing a new phenotype of distal myopathy and motor neuropathy. Neurology 2016:86:391-8.

w88 Dubrey S, Ackermann E, Gillmore J. The transthyretin amyloidoses: advances in therapy. Postgrad Med J 2015;91:439-48.

w89 El-Hattab AW, Scaglia F. Mitochondrial DNA depletion syndromes: review and updates of genetic basis, manifestations, and therapeutic options. Neurotherapeutics 2013;10:186-98 
w90 Schmidt WM, Rutledge SL, Schüle R, et al. Disruptive SCYL1 mutations underlie a syndrome characterized by recurrent episodes of liver failure, peripheral Neuropathy, Cerebellar Atrophy, and Ataxia. Am J Hum Genet 2015;97:855-61.

w91 Inoue K, Shilo K, Boerkoel CF, et al. Congenital hypomyelinating neuropathy, central dysmyelination, and Waardenburg-Hirschsprung disease: phenotypes linked by SOX10 mutation. Ann Neurol 2002;52:836-42.

w92 Dafsari HS, Byrne S, Lin JP, et al. Goldberg-Shprintzen megacolon syndrome with associated sensory motor axonal neuropathy. Am J Med Genet A 2015;167:1300-4

w93 Bedlack RS, Vu T, Hammans S, et al. MNGIE neuropathy: five cases mimicking chronic inflammatory demyelinating polyneuropathy. Muscle Nerve 2004;29:364-8.

w94 De Giorgio R, Pironi L, Rinaldi R, et al. Liver transplantation for mitochondria neurogastrointestinal encephalomyopathy. Ann Neurol 2016;80:448-55.

w95 Mead S, Gandhi S, Beck J, et al. A novel prion disease associated with diarrhea and autonomic neuropathy. N Engl J Med 2013;369:1904-14.

w96 Boyer O, Nevo F, Plaisier E, et al. INF2 mutations in Charcot-Marie-Tooth disease with glomerulopathy. N Engl J Med 2011;365:2377-88.

w97 Dibbens L, Schwake M, Saftig P, et al. SCARB2/LIMP2 deficiency in action myoclonus-renal failure syndrome. Epileptic Disord 2016;18:63-72.

w98 Haliloglu G, Maluenda J, Sayinbatur B, et al. Early-onset chronic axonal neuropathy, strokes, and hemolysis: inherited CD59 deficiency. Neurology 2015;84:1220-4. w99 Lehky TJ, Groden C, Lear B, et al. Peripheral nervous system manifestations of Chediak-Higashi disease. Muscle Nerve 2017;55:359-65.

w100 Tachi N, Sasaki K, Kusano T, et al. Peripheral neuropathy in four cases of group A xeroderma pigmentosum. J Child Neurol 1988;3:114-9.

w101 Voermans NC, Bönnemann CG, Lammens M, et al. Myopathy and polyneuropathy in an adolescent with the kyphoscoliotic type of Ehlers-Danlos syndrome. Am J Med Genet A 2009;149A:2311-6.

w102 Capuano A, Bucciotti F, Farwell KD, et al. Diagnostic exome sequencing identifies a novel gene, EMILIN1, associated with Autosomal-Dominant hereditary connective tissue disease. Hum Mutat 2016;37:84-97.

w103 Tracy JA, Dyck PJ. Porphyria and its neurologic manifestations. Handb Clin Neurol 2014;120:839-49.

w104Schlump JU, Perot C, Ketteler K, et al. Severe neurological crisis in a patient with hereditary tyrosinaemia type I after interruption of NTBC treatment. J Inherit Metab Dis 2008;31 Suppl 2(Suppl 2):S223-5.

w105Kleopa KA, Raizen DM, Friedrich CA, et al. Acute axonal neuropathy in maple syrup urine disease. Muscle Nerve 2001;24:284-7.

w106 Spiegel R, Shaag A, Edvardson S, et al. SLC25A19 mutation as a cause of neuropathy and bilateral striatal necrosis. Ann Neurol 2009;66:419-24. 